\title{
Gli organismi religiosi nella trasformazione della città europea: dal rilievo alla definizione di una identità urbana
}

\author{
Paolo Giandebiaggi \\ Chiara Vernizzi
}

Abstract

II contributo illustra gli esiti di uno studio condotto sulla città di Parma attraverso letture interdisciplinari volte a comprendere l'impatto degli organismi conventuali e monastici sulla strutturazione e la trasformazione del tessuto urbano del centro storico della città e si inserisce nell'ambito degli studi urbani applicati ai tessuti storici consolidati, in continuità con le numerose esperienze condotte in particolare nell'ambito torinese e napoletano.

La metodologia di studio, affrontato ricorrendo anche all'analisi dei tipi edilizi, vede l'utilizzo del rilievo architettonico e urbano degli organismi religiosi come strumento e, nel contempo, fine delle diverse tipologie di lettura e analisi svolte, individuando una metodologia di ricerca complementare e integrata all'analisi storica e storico-iconografica, che elegge la conoscenza di organismi religiosi complessi a strumento chiave per la comprensione delle trasformazioni indotte sulla città.

L'esito di questo studio ha condotto a risultati interessanti per la comprensione delle dinamiche insediative e di trasformazione del centro storico della città di Parma, in primis, ma più in generale delle città europee, individuando una metodologia applicabile in contesti similari a quello parmense che si prospetta utile anche nella prefigurazione delle dinamiche future di trasformazione urbana non solo riferite ai tessuti consolidati del centro storico.

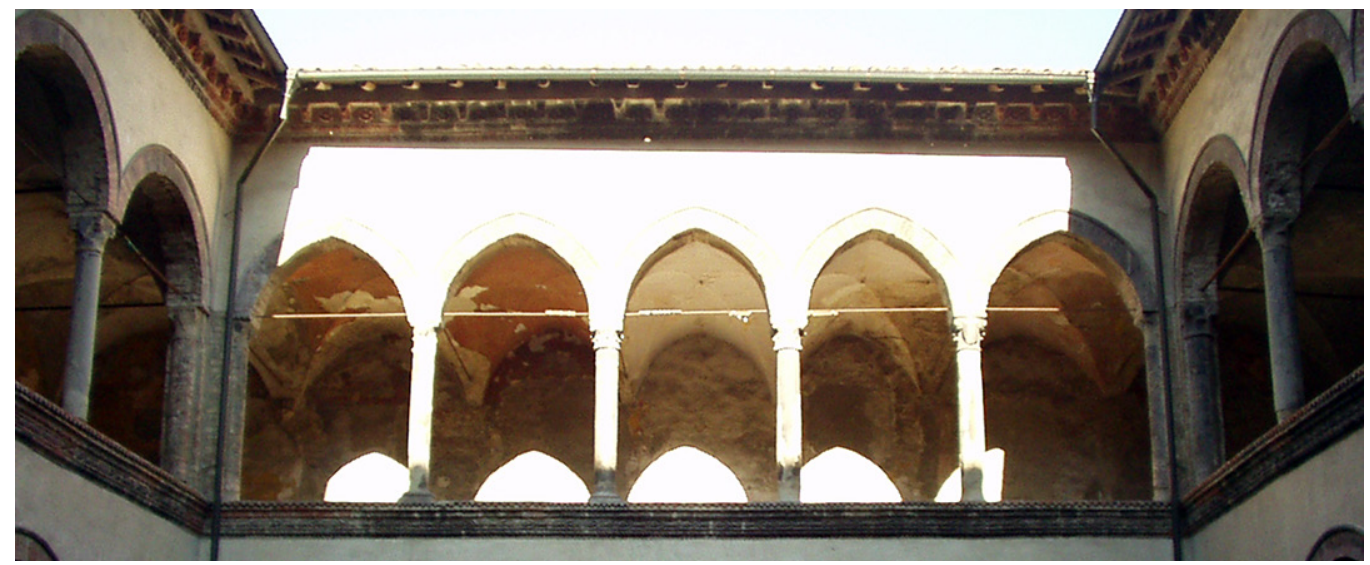




\section{Considerazioni introduttive}

Le città, in quanto grandi agglomerati di edifici pubblici e privati che si concentrano in alcune specifiche parti del territorio, compaiono almeno quattromila anni prima di Cristo. Questo scenario organizzato, che caratterizza le città greche prima e quelle romane poi, tende a mantenere la forma urbana dalla prima fondazione fino alla caduta dell'impero romano.

Dalla fondazione ai primi sviluppi delle città europee (come Parma ad esempio), si è giunti, alla fine del primo millennio, alla struttura urbana che vede una piazza civica principale, in cui sono presenti i principali luoghi del governo, ed una omologa piazza religiosa, nella quale si insedia il più alto potere religioso: così Parma, la città ad quadratum di fondazione romana, che aveva visto il consolidarsi della Piazza Grande all'incrocio originario di cardo e decumano, e della Mater Ecclesia all'angolo nord orientale dei margini urbani, si consolida attorno a questi due luoghi cardine.

La prospettiva cristiana denota però una rottura dei margini definiti e imposti introducendone uno nuovo, fatto di continue trasformazioni, anche morfologiche, in cui saranno proprio le chiese e gli edifici religiosi a determinare un rapporto con la città del tutto differente. Se si analizzano numericamente gli impatti dei differenti sistemi funzionali allinterno della città di Parma nei suoi sviluppi nel millennio successivo, appare subito chiaro come siano stati gli interventi di insediamento, costruzione e trasformazione degli organismi religiosi quelli che più di tutti hanno determinato lo sviluppo fisico e formale della città, inducendo l'accorpamento delle zone residenziali attorno ad essi e determinando il complessivo disegno del tessuto urbano.

Queste cellule 'religiose' che nel corso della storia hanno pervaso la città, continuando sempre a cambiarla ed a modificarla, sono di fatto il vero DNA della città europea ed in particolare della città italiana, Parma compresa.

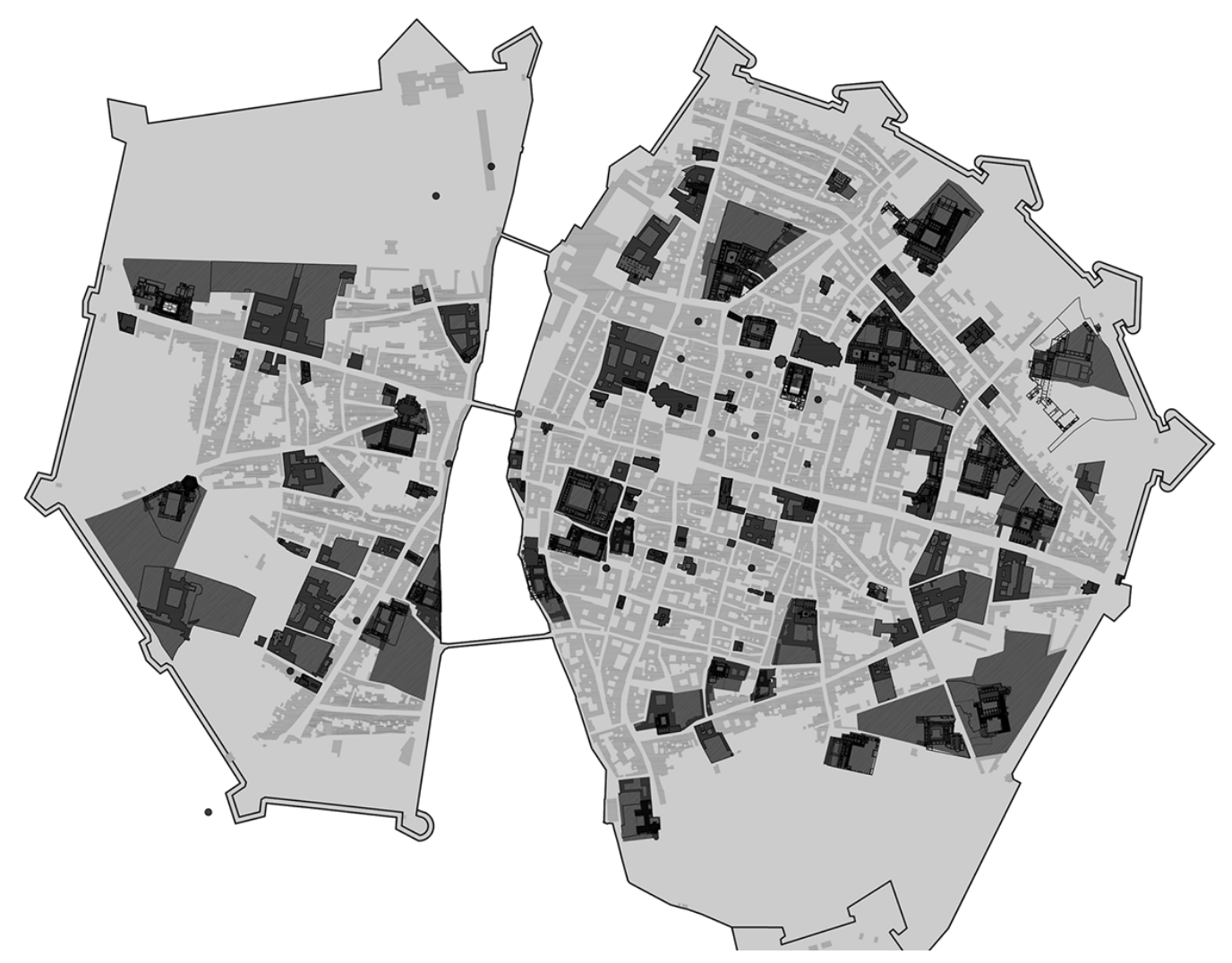


Fig. 2. Foto aerea del centro storico di Parma con la sovrapposizione della totalità dei fatti architettonici analizzati [elaborazione grafica di Donatella Bontempi da ortofoto aerea della Compagnia Generale Riprese Aeree, 2000].

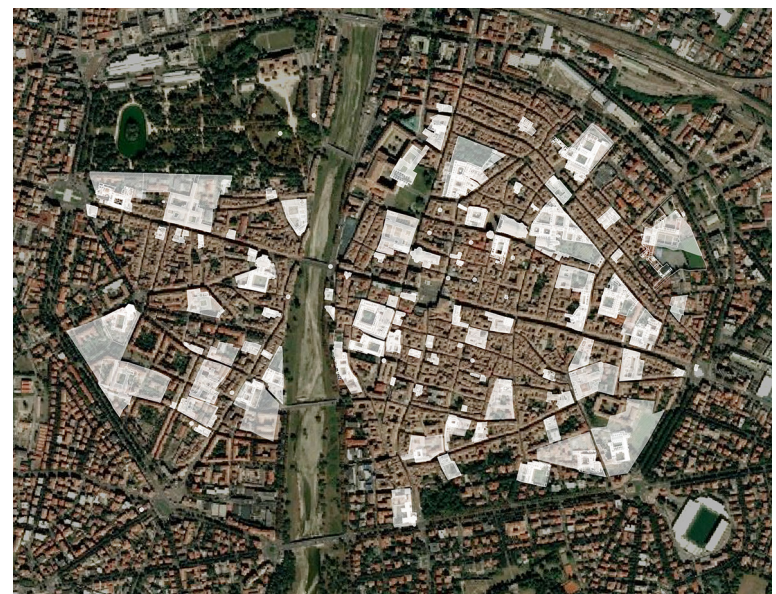

Lo studio compiuto sul tessuto parmense è stato condotto proprio partendo dalla lettura oggettiva di questi fenomeni, dalla loro catalogazione ed interpretazione, dando ai risultati stessi la possibilità di far comprendere come quelle esperienze possano essere utili nella comprensione dei fenomeni urbani contemporanei e nella miglior prefigurazione e pianificazione di quelli futuri.

\section{Questioni di metodo}

Dalla lettura della cartografia storica della città di Parma degli ultimi sei secoli, sono stati individuati, registrati, documentati e compresi tutti i fatti architettonici che si sono manifestati e che si caratterizzavano come realizzazioni prodotte per le funzioni religiose nelle differenti tipologie. Dalla lettura sincronica dei fatti diacronici avvenuti su ogni edificio avente una funzione riconducibile al tema religioso, si è analizzata la reazione della città nel suo

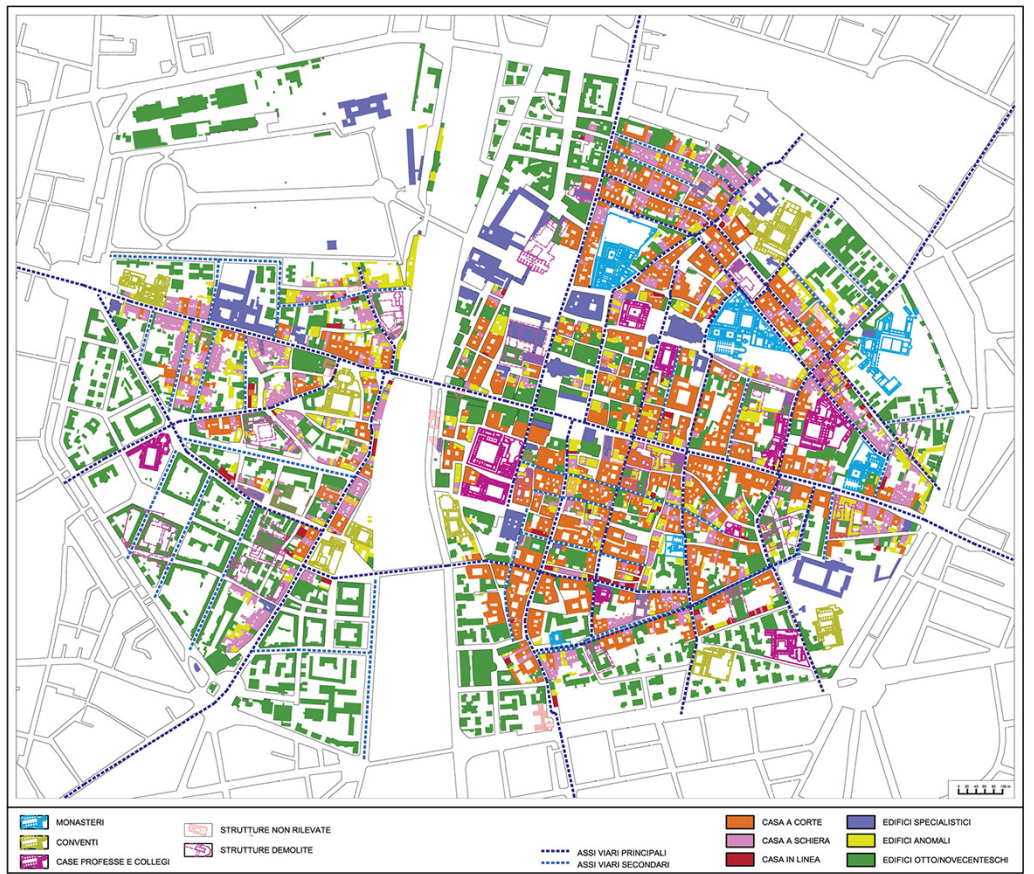

Fig. 3. Analisi tipologica del tessuto storico della città di Parma all'interno al tracciato delle mura del 1545 oltre alla localizzazione di monasteri conventi, collegi, case professe e ospizi gestiti da religiosi. Scala originale del disegno |:5.000. 
Fig. 4. Foto aerea del tessuto urbano dell'area circostante il monastero di San Paolo.

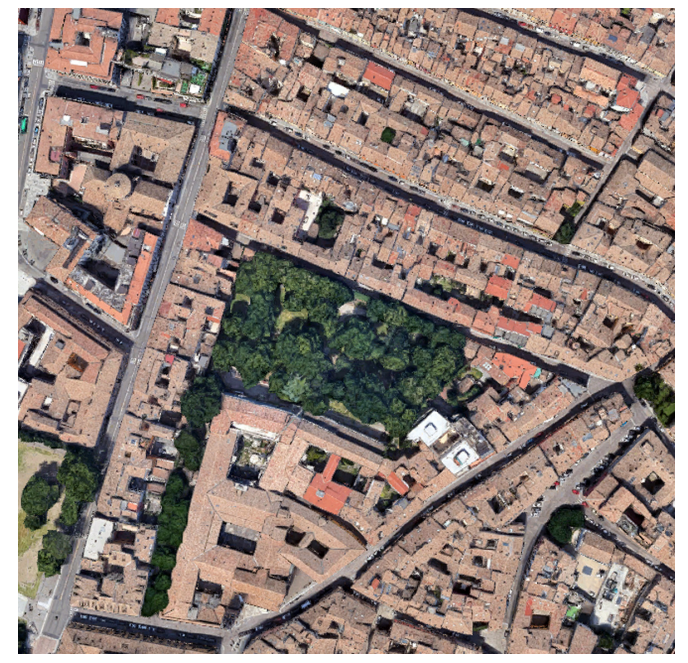

intorno. Non ci si è però limitati alla mera registrazione dei fatti architettonici specifici, ma è stato indagato come questi al loro variare, alla variazione dei fatti costruttivi o al variare delle funzioni, abbiano determinato e contaminato funzionalmente ed organizzativamente i loro rispettivi contesti urbani, le strade, le piazze, la dislocazione di altre funzioni urbane, disegnandoli in modo quasi esclusivo. Ogni parte della città è stata in diverso modo generata, trasformata, modificata e infine rigenerata da fatti inerenti i numerosissimi e differenti organismi religiosi che l'hanno popolata.

Dalla evoluzione della forma urbana complessiva, risulta evidente come la realizzazione delle prime strutture religiose medioevali immediatamente fuori dalle mura dell'epoca, abbiano

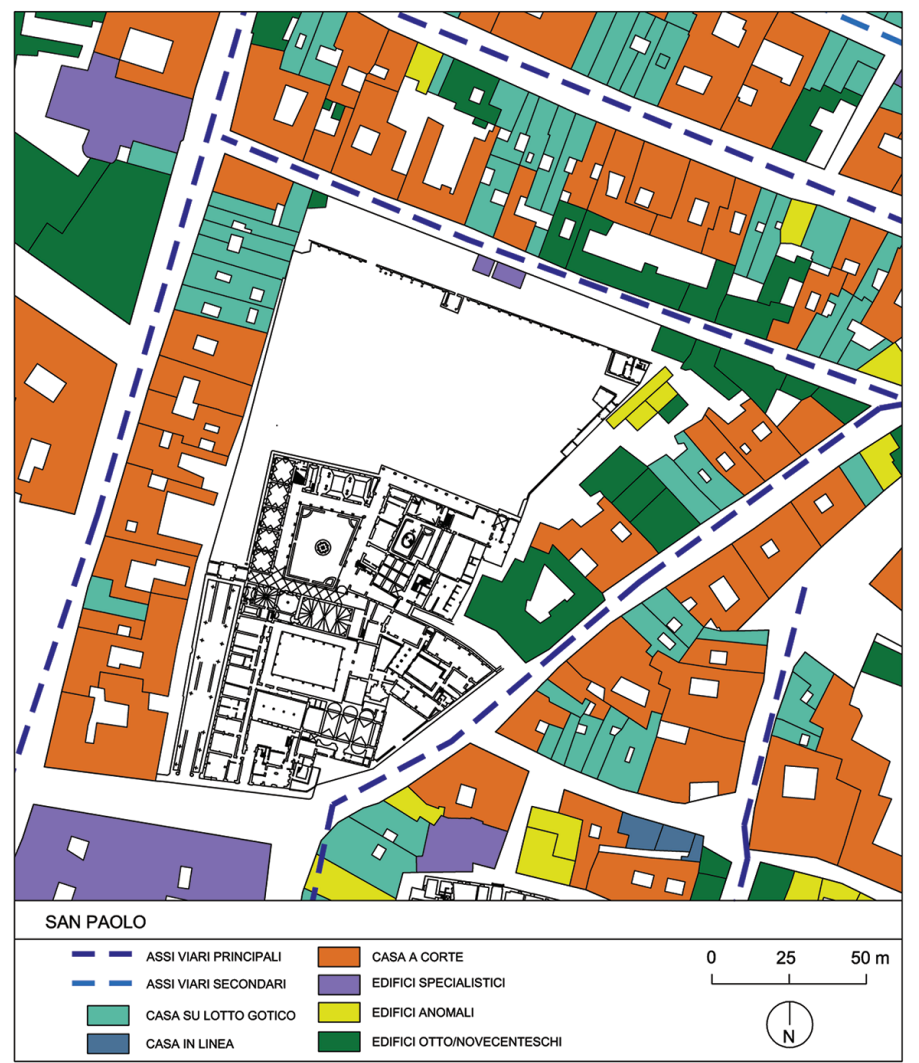

Fig. 5. Analisi tipologica del tessuto urbano dell'area circostante il monastero di San Paolo. Scala origina 
fin dall'inizio del secondo millennio caratterizzato la forma, l'organizzazione, la strutturazione della città, determinando un condizionamento impari rispetto ad ogni altra funzione, soprattutto in merito al suo sviluppo periferico (fig. I).

L'ulteriore insediamento e successiva trasformazione a metà del secondo millennio di tanti insediamenti religiosi ha costantemente determinato lo sviluppo urbano complessivo e la sua singolarità.

Alcuni di questi edifici sono rimasti avvolti da una permanenza spesso dettata dalla qualità architettonica ed artistica delle realizzazioni, ma anche da innumerevoli casi di riuso e trasformazione con funzioni laiche del tipo più vario.

Per ciascun organismo religioso, indipendentemente dalle sue specificità, è stata analizzata la ricaduta che lo stesso ha avuto non solo sulla genesi e sulla trasformazione urbana pertinente, ma anche su quella adiacente e quindi su settori della città molto ampi.

Lo studio ha complessivamente interessato I I4 organismi, tutti indagati, analizzati e verificati dal confronto cartografico dell'evoluzione urbana. I principali complessi architettonici di matrice religiosa tuttora presenti in città sono 26 , e su di essi sono stati realizzati rilievi architettonici restituiti digitalmente in scala 1:50 (fig. 2).

Questa indagine ha permesso di comprendere la matrice insediativa della città, l'evoluzione della sua forma, e le ragioni di quellidentità specifica che differenzia in modo irripetibile ogni città da un'altra, grazie al costante e continuo trasformarsi dei fatti architettonici in cui la Chiesa, almeno nella porzione di città storica, ha certamente il primato.

\section{Gli organismi religiosi e la trasformazione del tessuto urbano}

Per comprendere le dinamiche trasformative ed i condizionamenti indotti dalla costruzione degli organismi conventuali e monastici sul tessuto urbano circostante, è opportuno effettuare alcune considerazioni preliminari relative al tipo di struttura di cui si sta trattando poiché a seconda del diverso tipo di organismo e della relativa epoca di impianto, diverse sono le caratteristiche costruttive e tipologiche che gli sono proprie.

A seconda che la struttura considerata sia, infatti, un monastero, un convento o una struttura adibita a casa professa, ospedale, ospizio o collegio, diverso è il rapporto di mutuo condizionamento con l'esterno che la struttura intrattiene, non solo dal punto di vista dei legami fisici con il tessuto circostante, ma anche dal punto di vista percettivo e fruizionale che viene a caratterizzare l'intero contesto.

Proprio la diversa natura di conventi, monasteri e case professe, legata anche alle regole degli ordini insediati allinterno delle strutture, caratterizza infatti non solo gli aspetti tipologici,

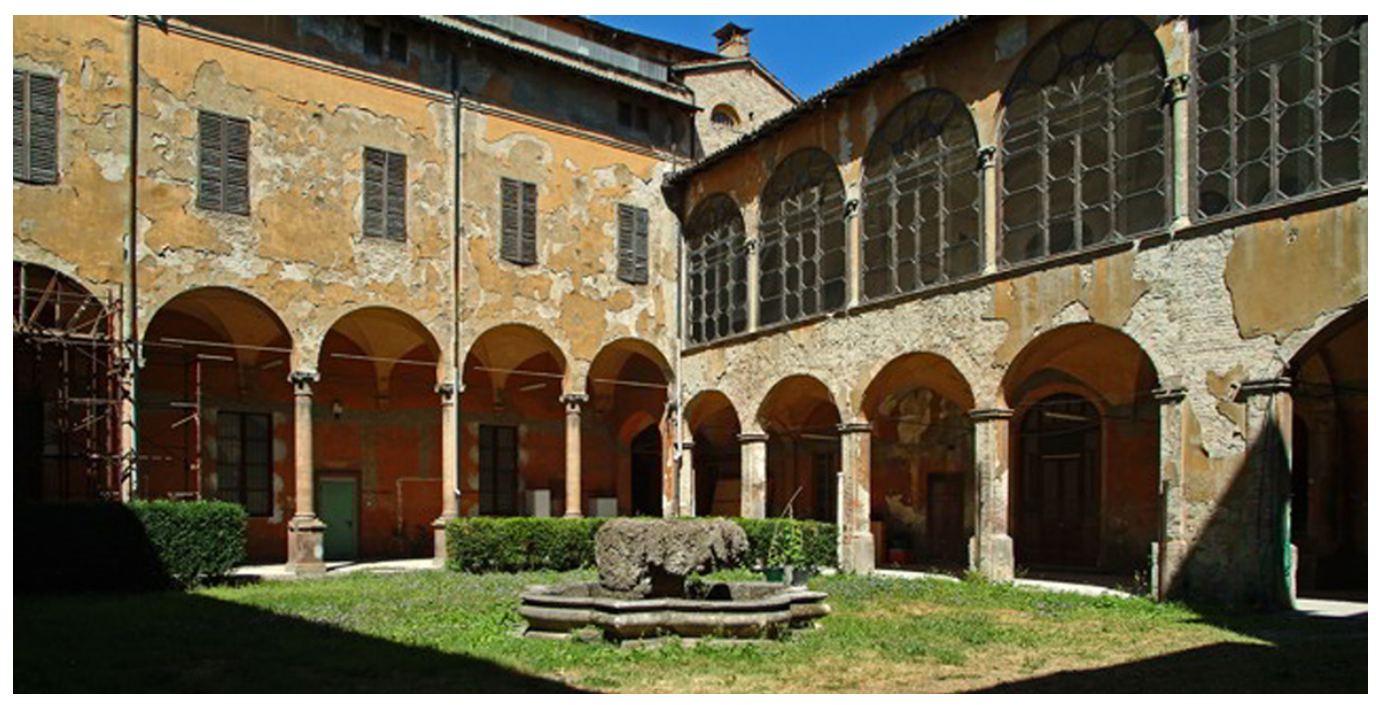


Fig. 7. Foto aerea del tessuto urbano dell'area circostante Convento di San Francesco del Prato.

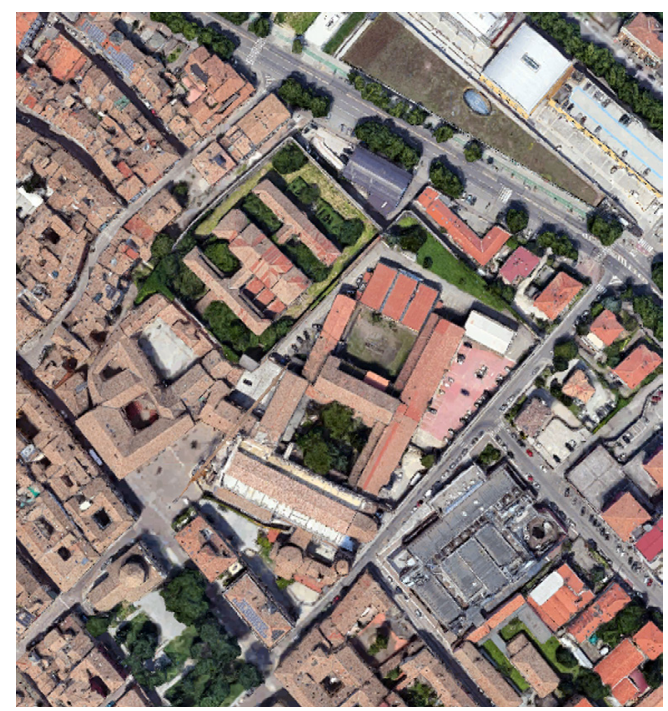

distributivi e fruitivi interni, ma anche la maggiore o minore 'apertura' verso l'esterno, il ruolo assunto dalle strutture destinate al culto, fino alla maggiore o minore presenza di strutture di supporto alla vita interna a questi organismi, legata al sostentamento di chi vi abita. Per analizzare in modo metodologicamente corretto e puntuale le ricadute sul tessuto urbano indotte dalla costruzione di queste strutture, bisognerebbe poter consultare la cartografia storica relativa alle singole epoche di impianto di ogni organismo analizzato, ma data, la lontananza nel tempo del momento di impianto dei sistemi oggetto di indagine, questa modalità di analisi del tessuto urbano per confronto cartografico effettuato a soglie storiche cronologicamente successive risulta impossibile.

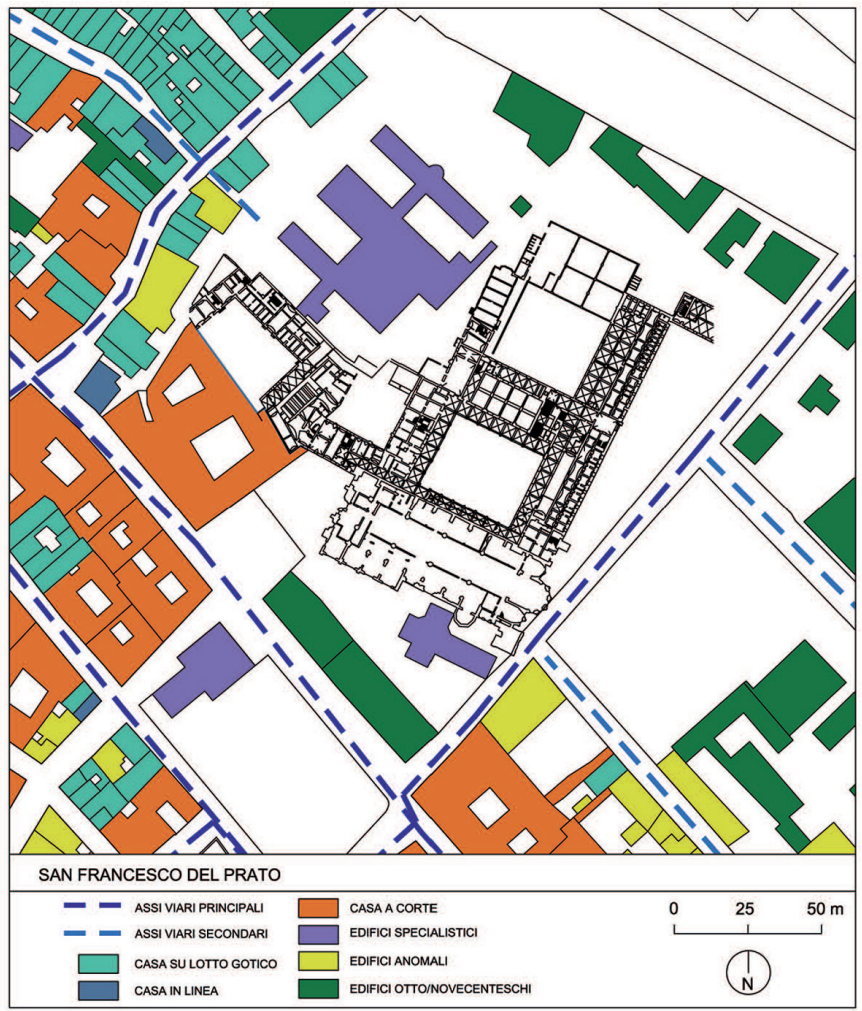


Per questo, alla ricerca di un metodo che consentisse comunque di conoscere e comprendere le dinamiche di trasformazione e condizionamento innescatesi sui diversi contesti di impianto degli organismi religiosi, si è ricorsi all'analisi tipologica del tessuto urbano del centro storico della città, utilizzando questa modalità di lettura dei fenomeni urbani come strumento di comprensione delle dinamiche insediative, associando, in senso cronologico, le diverse tipologie ancora oggi riconoscibili alle epoche storiche cui il loro impianto è riconducibile, con un margine di errore decisamente accettabile, vista la lontananza nel tempo delle epoche di cui si tratta.

Infatti dal riconoscimento delle diverse tipologie insediative storiche, relative in particolare all'edilizia residenziale, è possibile dedurre una datazione di massima dell'impianto del tessuto urbano, in associazione agli studi storici sulla forma e sull'estensione della città nelle diverse epoche, contestualizzando in senso temporale il rapporto tra impianto del tessuto residenziale e degli organismi religiosi, per arrivare a comprendere, attraverso questa contestualizzazione, le dinamiche di reciproco condizionamento intercorrenti tra gli organismi monastici e conventuali ed il tessuto al contorno.

Un'analisi tipologica effettuata sulla consistenza odierna del tessuto urbano considera però non solo il tessuto stesso nella sua forma attuale, ossia quale esito di numerose trasformazioni urbanistiche avvenute nel corso dei secoli, ma anche e soprattutto gli organismi religiosi così come oggi ci si presentano, vale a dire in una veste molto diversa da quella iniziale, spesso frutto di rifondazioni quattro-cinquecentesche che hanno fortemente alterato lo stato originario delle strutture, sia dal punto di vista tipologico che dimensionale.

Il tipo edilizio (casa su lotto gotico, casa a corte, casa in linea, edifici specialistici, edifici anomali, edilizia otto/novecentesca), attraverso lo studio dei suoi parametri caratteristici (assetto strutturale e distributivo, modi di aggregazione) è stato dunque utilizzato come codice

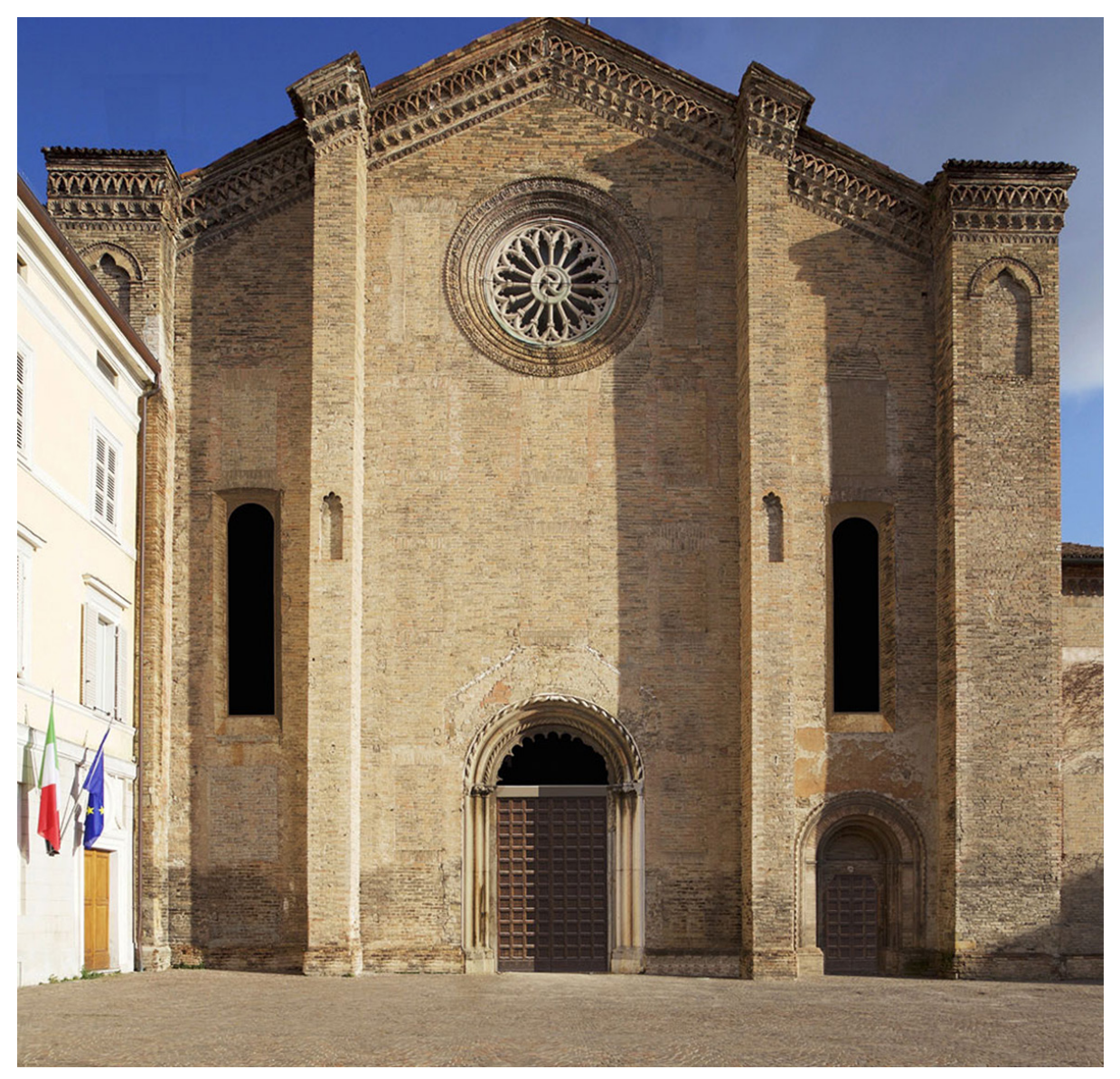


Fig. 10. Foto aerea del tessuto urbano dell'area circostante Convento della Santissima Annunziata.

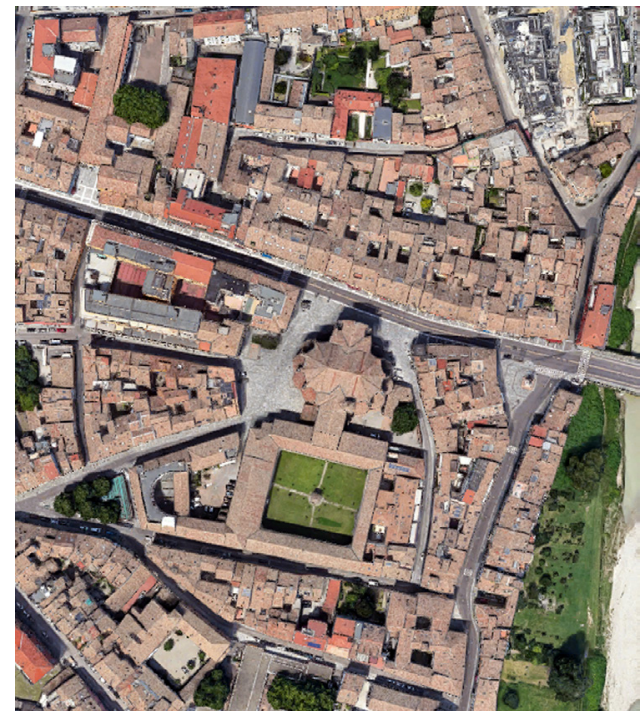

interpretativo del tessuto urbano, consentendo una datazione di massima delle strutture adiacenti agli organismi religiosi analizzati (fig. 3).

Attraverso tali letture sono emerse considerazioni interessanti, che portano in primo luogo ad individuare due diverse categorie di condizionamento: quello indotto dalle strutture monastiche e conventuali sul tessuto urbano e sui percorsi, nel caso di insediamenti in aree esterne al tessuto già consolidato, e quello soprattutto subito dalle strutture stesse da parte dei percorsi e degli edifici esistenti, nel caso di insediamenti dove il tessuto era già compatto, consolidato nella sua morfologia e nella sua strutturazione 'urbanistica'.

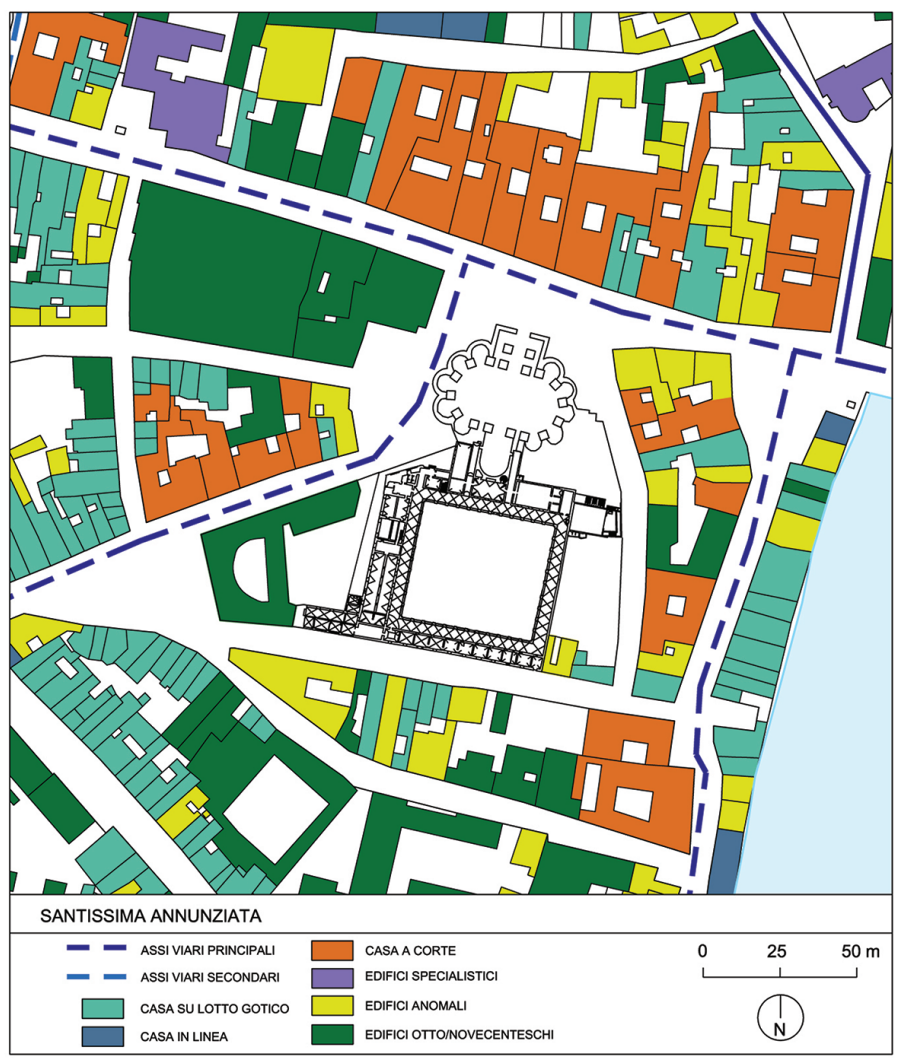

Fig. I I. Analisi tipologica del tessuto urbano dell'area circostante il Convento della Santissima Annunziata. Scala originale del disegno l:2.500. 
Come di consueto, l'analisi è stata svolta utilizzando il disegno prima come strumento di lettura e indagine e poi come mezzo di rappresentazione grafica degli esiti dell'analisi precedente, caratterizzandosi come elemento di connessione tra passato e presente, volto alla comprensione delle peculiarità delle trasformazioni urbane avvenute.

La lettura/interrogazione del tessuto urbano si è, inoltre, approfondita passando dalla scala urbana alla scala architettonica, dove le strutture sono ancora oggi esistenti e quindi visitabili e rilevabili, attraverso l'indagine delle motivazioni funzionali d'impianto, che consentono la conoscenza delle destinazioni d'uso attualmente prevalenti rispetto a quelle originarie, e dei caratteri edilizi relativi in particolare all'organizzazione planimetrica del corpo principale, al percorso di ingresso e scala, all'organizzazione degli spazi dei chiostri e dei giardini.

Dalla lettura della cartografia urbana con la localizzazione delle strutture monastiche, di più remota fondazione, emerge con chiarezza come questi organismi, per lo più di grandi dimensioni, si siano insediati in aree esterne alla cinta muraria dell'epoca, attestandosi lungo i principali percorsi di uscita dalla città in direzione di altri importanti poli urbani presenti nel territorio, subendo, quindi, un condizionamento dalle infrastrutture viarie e dai canali, lungo i quali si insediavano per consentire le attività produttive interne.

Analizzando ad esempio il monastero di San Paolo (figg. 4, 5, 6), emerge come il tessuto urbano sia caratterizzato da isolati lineari disposti lungo i percorsi stradali che definiscono i confini del monastero, al cui interno si dispongono prevalentemente categorie tipologiche riconducibili alle case a corte, nel primo tratto, e alla casa su lotto gotico nella parte rivolta verso nord; la presenza di ampie zone caratterizzate da una morfologia edilizia composta da singole cellule a lotto gotico, in particolare nei pressi delle strutture monastiche, va messa in relazione al grande numero di pertinenze accessorie alle strutture religiose, che diedero impulso alla costruzione in enfiteusi di un grande numero di abitazioni per le persone che a vario titolo avevano a che fare con l'economia dei monasteri.

Diverso è, invece, il discorso relativo alle strutture conventuali, per le quali è difficile poter rintracciare modalità unitarie di rapporto con il contesto, sia come condizionamento subìto dall'intorno sia come indotto su di esso: a titolo di esempio, basti pensare ai conventi di San Francesco del Prato (figg. 7, 8,9) e San Luca degli Eremitani, forse i più antichi insediatisi in città e di cui ancora oggi esistono le strutture, entrambe dismesse: entrambi questi conventi infatti si sono insediati in ampi isolati aventi forme irregolari, definite dai percorsi di uscita

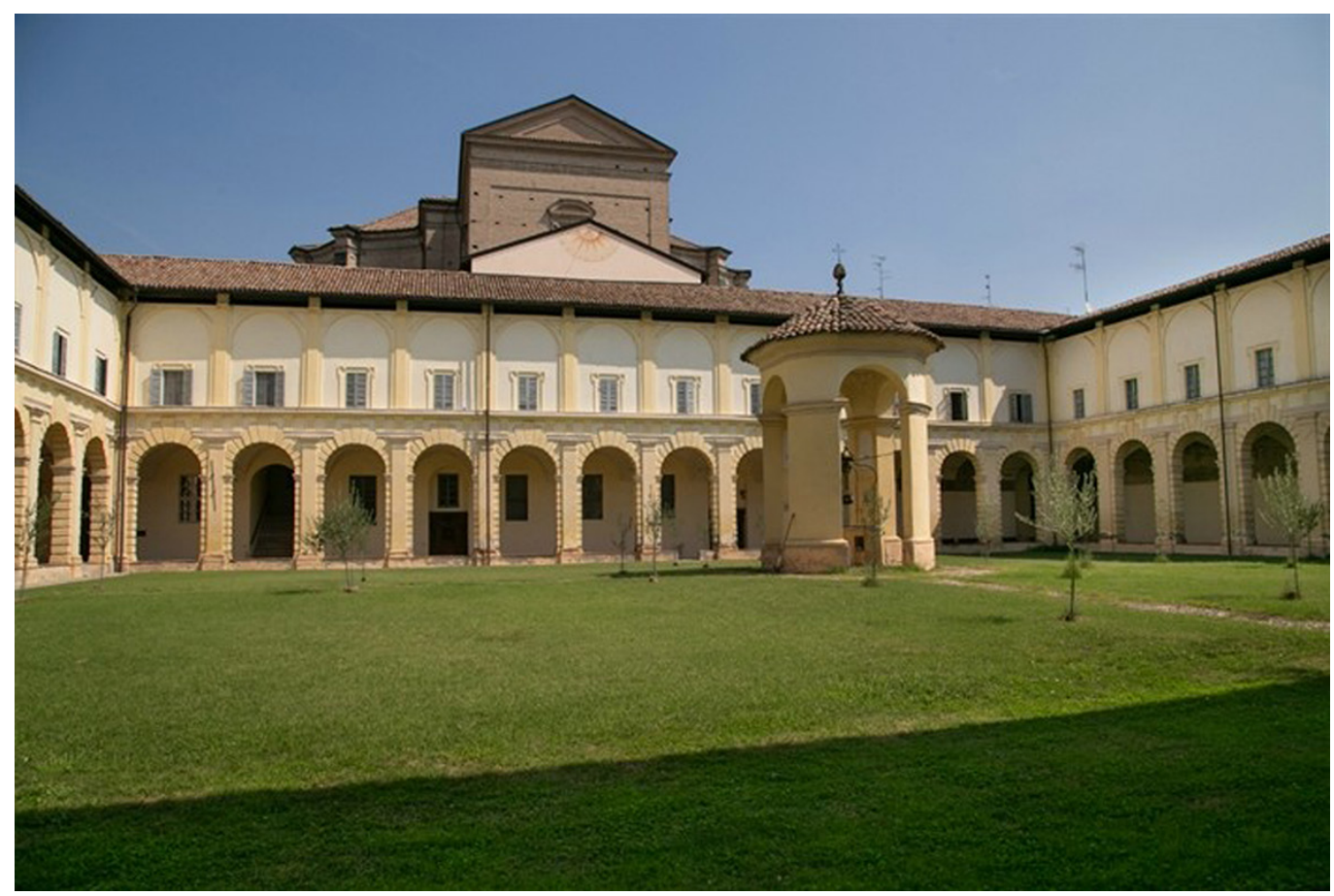


dalla città, ma non si sono adeguati agli orientamenti da essi stabiliti e intorno a loro la città è cresciuta in modo diverso.

Alcuni organismi conventuali risultano fortemente soggetti a condizionamenti da parte dei percorsi lungo i quali si attestano, spesso senza provocare ricadute sulla morfologia urbana del tessuto circostante, come nel caso di Santa Maria del Carmine, letteralmente incuneata tra il letto del torrente e il sedime delle mura del I 100.

Diversi per storia ed epoca d'insediamento, o meglio, rifondazione, sono i casi dei seicenteschi conventi di San Francesco di Paola (fig. 13) e dell'Annunziata (figg. 10, II, 12) nell'Oltretorrente, che si sono insediati in un tessuto già strutturato, che hanno a loro volta condizionato in modo forte ma con diverse modalità.

I condizionamenti sul tessuto urbano di cui abbiamo notizie più dettagliate riguardano le trasformazioni avvenute successivamente alla soppressione degli ordini religiosi ed al conseguente riuso delle strutture, che hanno subito numerose modifiche per potersi adeguare alle nuove funzioni insediate; ovviamente, le più evidenti riguardano la sostituzione di alcuni corpi di fabbrica, attraverso la demolizione e ricostruzione di quelli che con più difficoltà si adattavano ad ospitare le nuove funzioni oppure di quelli che in origine accoglievano funzioni marginali rispetto al complesso, con forti ricadute sul disegno urbano dell'immediato contesto di appartenenza.

\section{Considerazioni conclusive}

Monasteri, conventi, collegi, ospizi, prima nel loro insediarsi, poi nella loro crescita e nella loro continua trasformazione nel tempo, sono risultati elementi caratterizzanti le dinamiche evolutive urbane, a partire dal loro inurbamento, fino alle rifondazioni, ampliamenti, accorpamenti e modificazioni, in quanto l'insediamento e l'evoluzione dell'architettura specialistica ha agito da propulsore per numerosi cambiamenti di carattere economico, funzionale e sociale che si sono tradotte nella modificazione dei contesti urbani relativi ai singoli complessi religiosi.

Ad esclusione del luogo di culto per eccellenza, la chiesa, sono gli organismi ad essa collegati che hanno determinato, sia per dimensione che per funzione, una copertura del territorio urbano talmente rilevante da caratterizzare morfologicamente la città, non solo negli isolati di stretta pertinenza, ma anche in quelli immediatamente adiacenti.

Soprattutto attraverso le parti funzionalmente più deboli in quanto accessorie, che come ramificazioni si sono articolate dai corpi principali, solitamente più resistenti alle trasformazioni, i sistemi religiosi hanno dialogato con il tessuto urbano in una dinamica trasformativa molto vivace, che ha visto soprattutto le parti più marginali dei complessi modificarsi, scomparire o essere sostituite da altri corpi di fabbrica, che instaurano rapporti nuovi con il tessuto circostante, mutando l'immagine urbana.

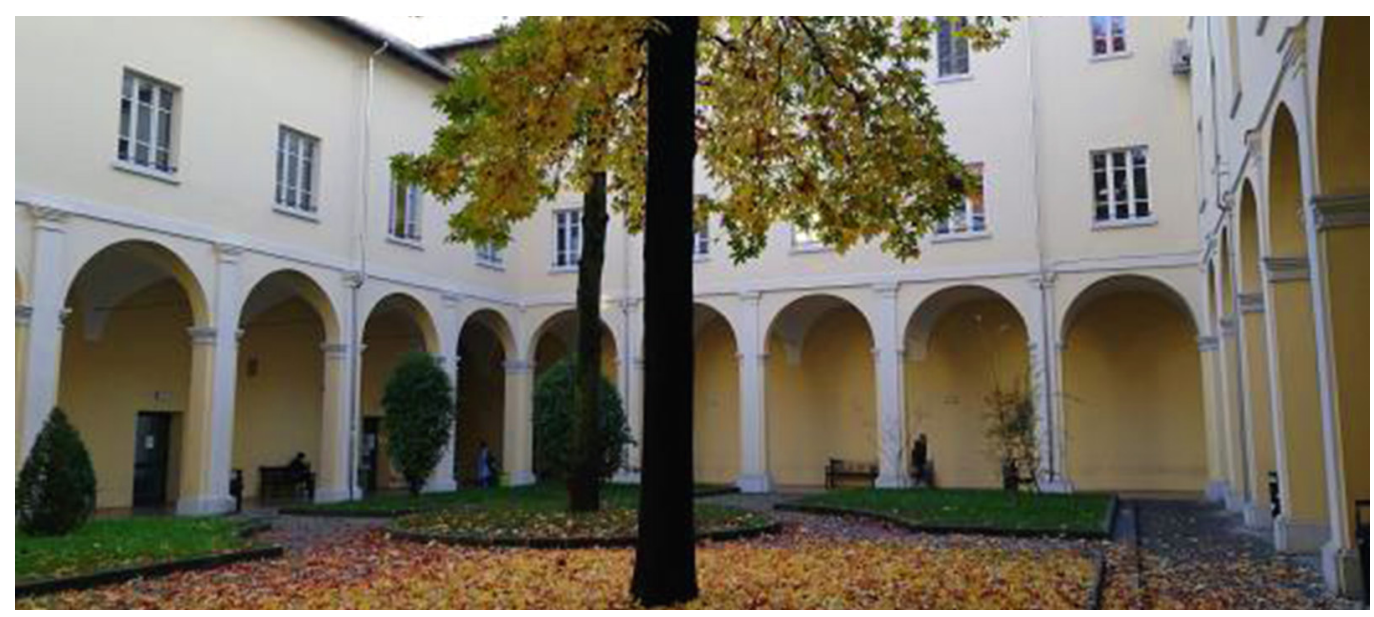




\section{Riferimenti bibliografici}

Aymonino Carlo (1966). Origini e sviluppo della città moderna. Padova: Marsilio.

Baculo Giusti Adriana (1996). Napoli al quattromila, assonometria e pianta sinottica della città. Napoli: Electa.

Banzola Vincenzo (a cura di). (1978). Parma: La città storica. Parma: Cassa di Risparmio di Parma.

Bertocci Stefano, Parrinello Sandro (a cura di). (20I3). Architettura eremitica: sistemi progettuali e paesaggi culturali. Atti del $4^{\circ}$ Convegno internazionale di studi. Camaldoli 21 -23 settembre 2013. Firenze: Edifir.

Cavallari Murat Augusto(1968). Metodologia e metodi in tema di rioni storici: rinnovamento nel rilievo urbanistico-architettonico Torino: UTET.

Caniggia Gianfranco, Maffei Gian Luigi (1979). Composizione architettonica e tipologia edilizia. I: Lettura dell'edilizia di base. Venezia: Marsilio.

Comune di Parma Assessorato All'urbanistica (a cura di). ( 1979). Disciplina particolareggiata per gli interventi nel Centro Storico: Variante al piano regolatore generale: Relazione Generale. Parma: Comune di Parma.

Conte Antonio (1996). II disegno degli ordini: Monasteri, conventi, abbazie e grancie della Basilicata, Potenza: Ermes.

Coppo Secondino, Boido Cristina (a cura di). (20l0). Rilievo urbano. Conoscenza e rappresentazione della città consolidata. Firenze: Alinea.

Cundari Cesare, Carnevali Laura (a cura di). (2003). Il rilevamento urbano: tipologia, procedure, informatizzazione: Materiali della ricerca co-finanziata dal MIUR nel 2000. Roma: Kappa edizioni.

Cundari Cesare (a cura di). (2005). Il rilievo urbano per sistemi complessi: Un nuovo protocollo per un sistema informativo di documentazione e gestione della citta: Materiali dalla ricerca co-finanziata dal MIUR nel 2002. Roma: Kappa edizioni.

Da Mareto Felice (1975). Parma e Piacenza nei secoli: Piante e vedute cittadine delle antiche e nuove province parmensi. Parma: Deputazione di storia patria per le province parmensi: Rotary Club.

Dalcò Fabrizia (20 I5). Monasteri e conventi femminili nella Parma medievale. Parma: Nuova Editrice Berti.

Giandebiaggi Paolo, Melley Maria Evelina, Vernizzi Chiara et al. (a cura di) (2019). Gli organismi religiosi nella trasformazione urbana. Analisi e rilievo nella città di Parma. Roma: Aracne Editrice.

Mandelli Emma, Duvernoy Sylvie (a cura di). (2002). Il disegno della città: opera aperta nel tempo.Atti del convegno internazionale AED, San Gimignano 29-30 giugno 2002. Firenze: Alinea.

Melley Maria Evelina (2012). I chiostri negli organismi religiosi di Parma. Geometria, proporzioni, architettura. Fidenza (PR): Mattioli 1985

Miani Uluhogian Franca (1984). Le immagini di una città: Parma (secoli XV-XIX): Dalla figurazione simbolica alla rappresentazione topografica. Parma: Casanova.

Mumford Lewis (1963). La città nella storia.Voll. I-3. Milano: Edizioni di Comunità.

Rossi Michela (2004). Strade d'acqua: Navigli, canali e manufatti idraulici nel parmense: Dal rilievo del territorio al disegno del paesaggio. Fidenza (PR): Mattioli 1885.

Vernizzi Chiara (2004). Parma e la via Emilia. Città storica, città moderna e asse fondativo: Rilievo e rappresentazione. Fidenza (PR): Mattioli 1885

Vernizzi Chiara, Bontempi Donatella (2015). La rappresentazione della città per lo studio dei fenomeni urbani. Evoluzione metodologica attraverso casi studio. In Marotta Anna, Novello Giuseppina (a cura di). Disegno \& città: cultura, arte, scienza, informazione. Atti del $37^{\circ}$ Convegno Internazionale dei docenti delle discipline della rappresentazione. Torino I7- 19 settembre 20 I5. Roma: Gangemi editore, pp. 87|-878.

\section{Autori}

Paolo Giandebiaggi, Università di Parma, paolo.giandebiaggi@uniprit

Chiara Vernizzi, Università di Parma, chiara.vernizzi@unipr.it

Per citare questo capitolo: Giandebiaggi Paolo,Vernizzi Chiara (2020). Gli organismi religiosi nella trasformazione della città europea: dal rilievo alla definizione di una identità urbana/Religious building in the transformation of the European city: from survey to the definition of an urban identity In Arena A., Arena M., Brandolino R.G., Colistra D., Ginex G., Mediati D., Nucifora S., Raffa P. (a cura di). Connettere. Un disegno per annodare e tessere. Atti del $42^{\circ}$ Convegno Internazionale dei Docenti delle Discipline della Rappresentazione/Connecting. Drawing for weaving relationships. Proceedings of the 42th International Conference of Representation Disciplines Teachers. Milano: FrancoAngeli, pp. | | 61-1 82 


\title{
Religious Building in the Transformation of the European City: from Survey to the Definition of an Urban Identity
}

\author{
Paolo Giandebiaggi \\ Chiara Vernizzi
}

\section{Abstract}

The paper illustrates the results of a study conducted on the city of Parma through interdisciplinary readings aimed at understanding the impact of conventual and monastic building on the structuring and transformation of the urban structure of the city's historic center and is part of the urban studies applied to the consolidated historical city, in continuity with the numerous experiences conducted in particular in Turin and Naples.

The study methodology, faced also through the analysis of building types, sees the use of the architectural and urban survey of religious organisms as a tool and, at the same time, the end of the different types of reading and analysis carried out, identifying a research methodology complementary and integrated to historical and historical-iconographic analysis, which elects the knowledge of complex religious organisms as a key tool for understanding the transformations induced on the city. The outcome of this study has led to interesting results for the understanding of the dynamics of settlement and transformation of the historical center of the city of Parma, first of all, but more generally of European cities, identifying a methodology applicable in contexts similar to Parma, which is also useful in the foreshadowing of future dynamics of urban transformation not only referred to the consolidated fabric of the historic center.

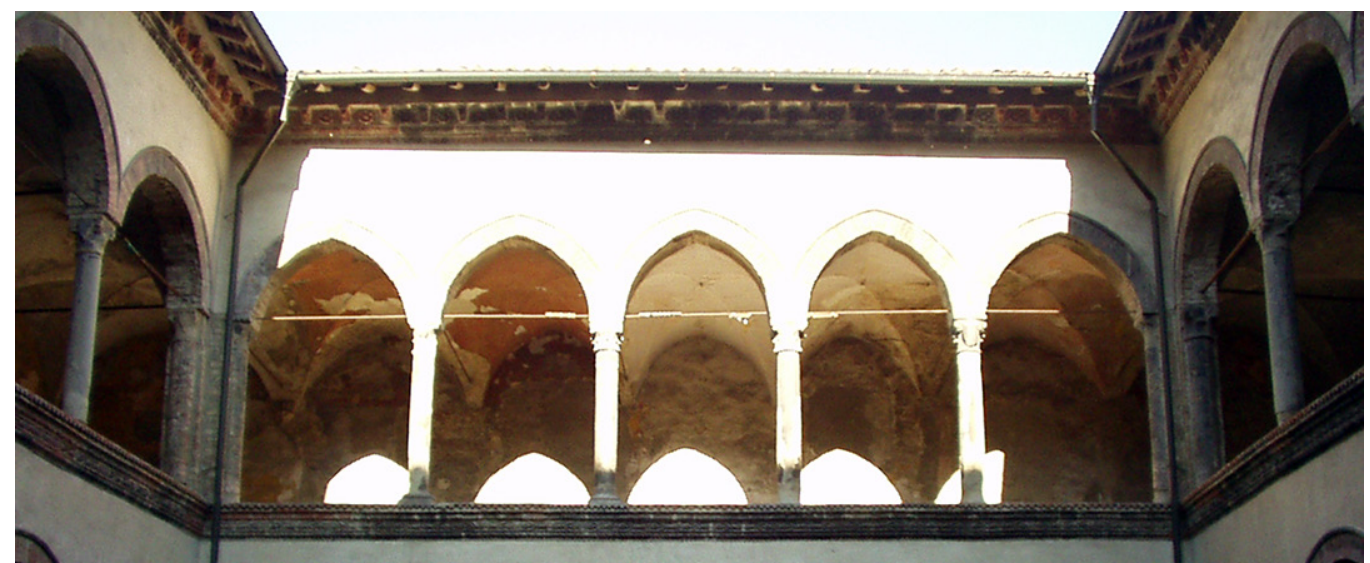




\section{Introduction}

Cities, as large agglomerations of public and private buildings concentrated in specific parts of the territory, appear at least four thousand years before Christ. This organized scenario, which characterizes Greek cities first and Roman cities later, tends to maintain the urban form from the first foundation until the fall of the Roman Empire.

From the foundation to the first developments of European cities (such as Parma for example), at the end of the first millennium, the urban structure has been developed, with a main civic square, where the main places of government are located, and a homologous religious square, where the highest religious power was established: thus Parma, the city ad quadratum of Roman foundation, which had seen the consolidation of the Piazza Grande at the original intersection of cardus and decumanus, and the Mater Ecclesia at the north-eastern corner of the urban edges, consolidated around these two pivotal places.

The Christian perspective, however, denotes a break in the defined and imposed margins, introducing a new one, made up of continuous transformations, including morphological ones, in which the churches and religious buildings will determine a completely different relationship with the city.

If we analyze numerically the impacts of the different functional systems within the city of Parma in its development in the following millennium, it is immediately clear how the interventions of settlement, construction and transformation of religious buildings have been the ones that most of all determined the physical and formal development of the city, inducing the unification of residential areas around them and determining the overall design of the urban built.

These 'religious' cells that have pervaded the city throughout history, always continuing to change and modify it, are in fact the true DNA of the European city and in particular of the Italian city, including Parma.

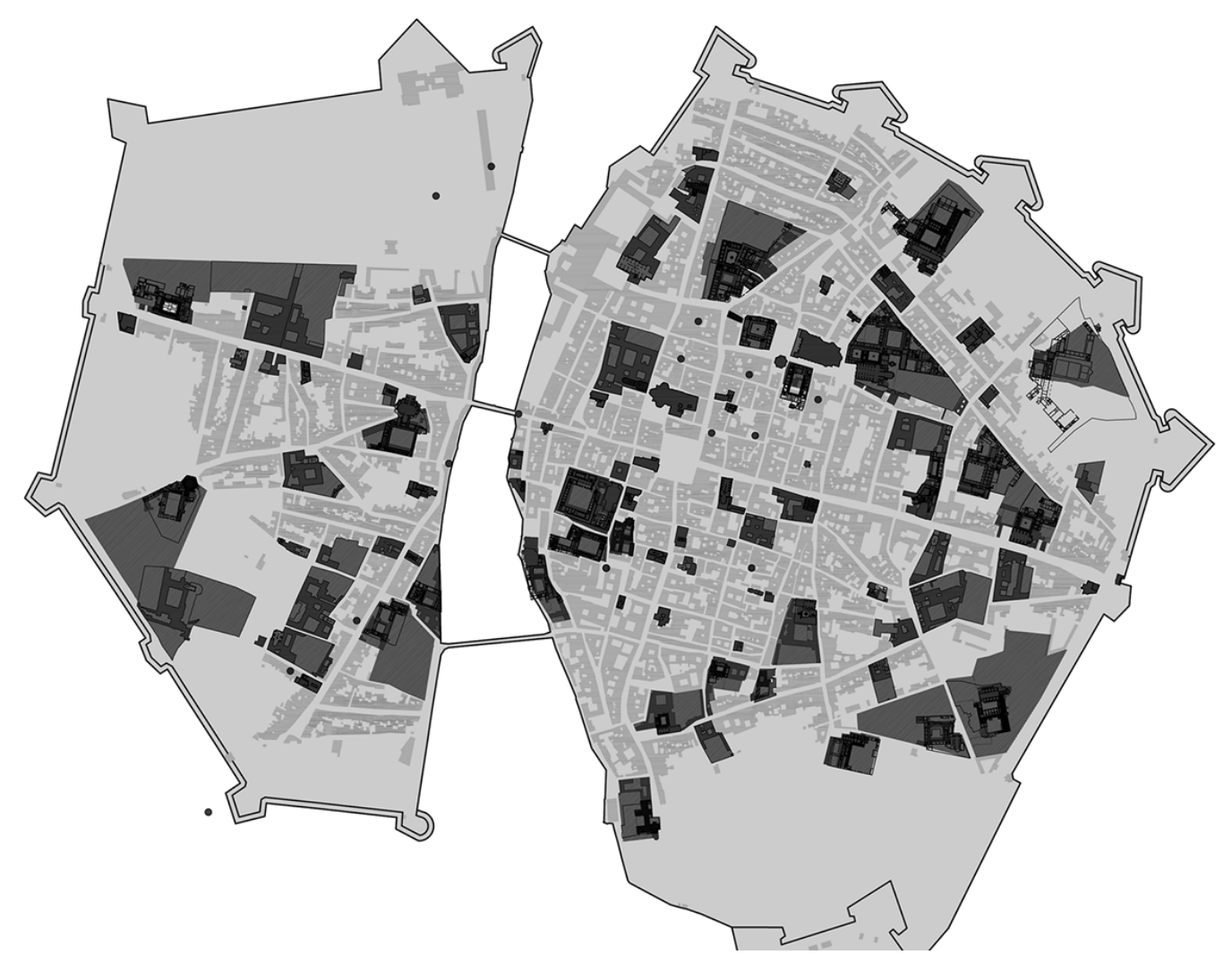


Fig. 2. Aerial photo of the historical center of Parma with the superimposition of the totality of the architectural facts analyzed [graphic elaboration by Donatella Bontempi from the aerial orthophoto of Compagnia Generale Riprese Aeree, 2000].

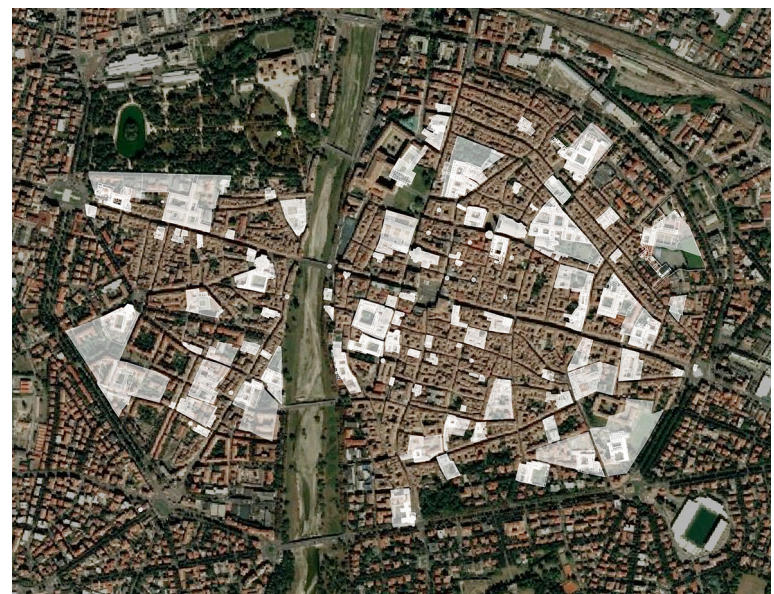

The study carried out on the Parma historic center has been carried out starting from the objective reading of these phenomena, their cataloguing and interpretation, giving the results themselves the possibility to make people understand how those experiences can be useful in the understanding of contemporary urban phenomena and in the best prefiguration and planning of future ones.

\section{Method issues}

From the reading of the historical cartography of the city of Parma of the last six centuries, all the architectural facts that have been manifested and that were characterized as realizations produced for religious functions in different typologies have been identified, recorded, documented and understood. From the synchronic reading of the diachronic events that occurred on each building having a function related to the religious theme, the reaction of

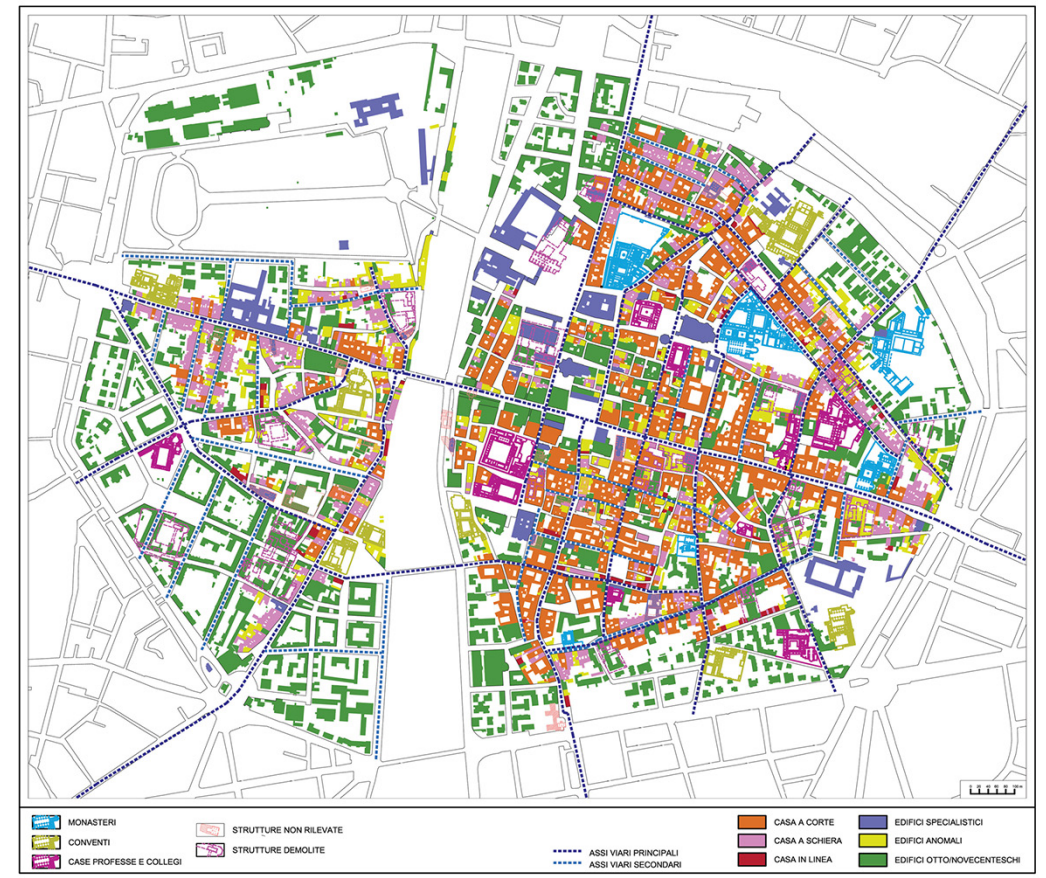

Fig. 3. Typological analysis of the historical buildings of the city of Parma within the layout of the 1545 walls as well as the location of monasteries, convents, colleges, hospices run by religious people. Original scale of the drawing 1:5.000. 


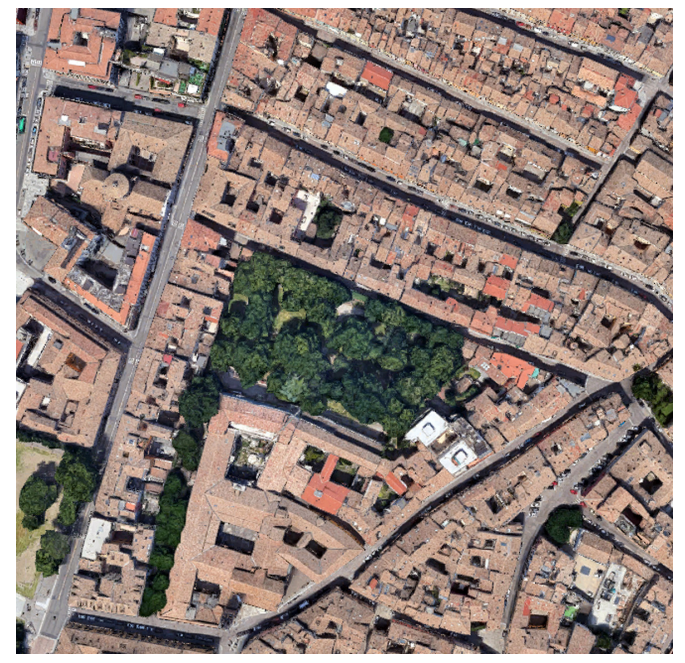

the city in its surroundings was analyzed. However, it has not been limited to the mere recording of specific architectural facts, but it has been investigated how they have determined and contaminated functionally and organizationally their respective urban contexts, streets, squares, the location of other urban functions, drawing them almost exclusively. Every part of the city has been generated, transformed, modified and finally regenerated in different ways by facts concerning the numerous and different religious buildings that have populated it. From the evolution of the overall urban form, it is clear that the construction of the first medieval religious structures immediately outside the walls of the time, have since the beginning of the second millennium characterized the form, organization, structure of the

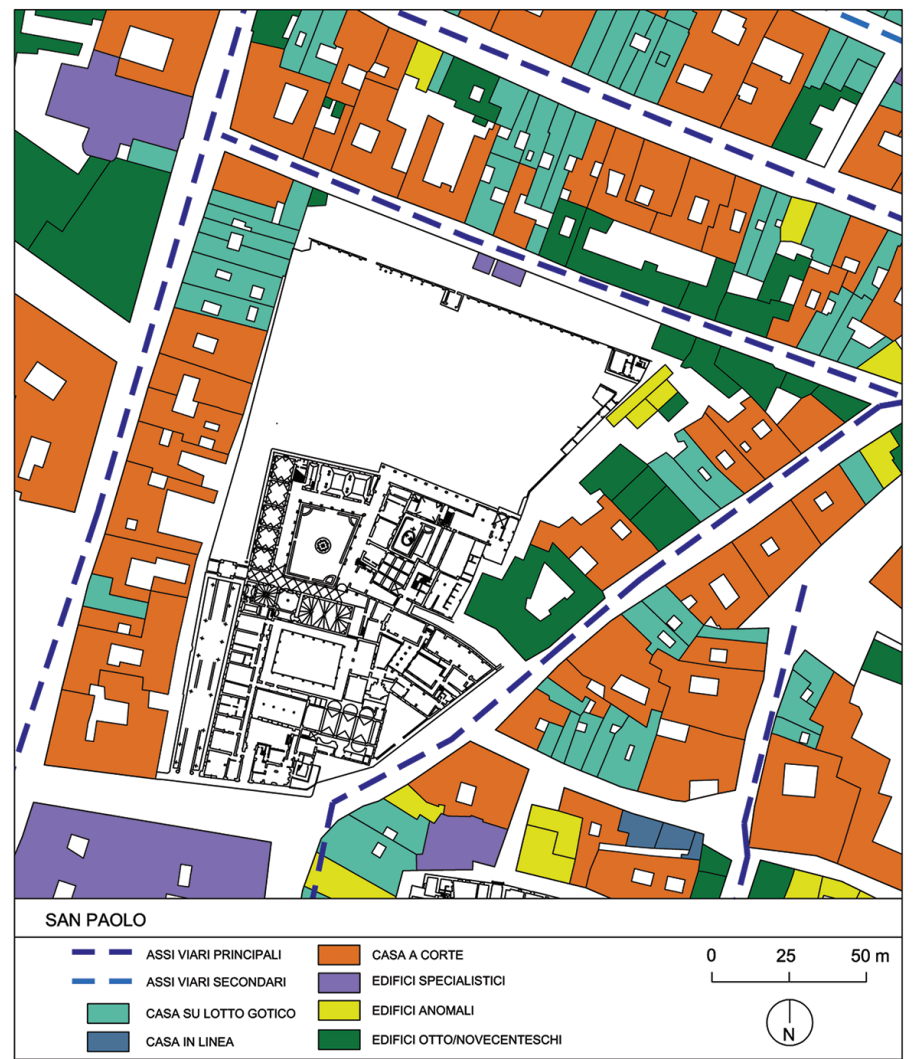


city, determining a conditioning unequal to any other function, especially with regard to its peripheral development (fig. I).

The further settlement and subsequent transformation in the middle of the second millennium of many religious settlements has constantly determined the overall urban development and its singularity.

Some of these buildings have remained shrouded in a permanence often dictated by the architectural and artistic quality of the achievements, but also by countless cases of reuse and transformation with secular functions of the most varied kind.

For each religious organism, regardless of its specificity, the impact that it has had not only on the genesis and the relevant urban transformation, but also on the adjacent one and therefore on very large sectors of the city has been analyzed.

The study involved a total of I 4 organisms, all investigated, analysed and verified by the cartographic comparison of urban evolution. The main architectural complexes of religious matrix still present in the city are 26, and architectural surveys have been made on them, digitally represented on a scale of 1:50 (fig. 2).

This investigation has made it possible to understand the settlement matrix of the city, the evolution of its shape, and the reasons for that specific identity that differentiates each city from another in an unrepeatable way, thanks to the constant and continuous transformation of the architectural facts in which the Church, at least in the portion of the historical city, certainly has the primacy.

\section{Religious buildings and the transformation of the historical city}

In order to understand the transformative dynamics and the conditioning induced by the construction of the conventual and monastic organisms on the surrounding historical city, it is appropriate to make some preliminary considerations regarding the type of structure that is being dealt with because, depending on the different type of organism and the relative time of settlement, the construction and typological characteristics are different.

Depending on whether the building considered is, in fact, a monastery, a convent or a structure used as a professed house, hospital, hospice or boarding school, different is the relationship of mutual conditioning with the outside that the building has, not only from the point of view of physical ties with the surrounding buildings, but also from the perceptual and fruitional point of view that comes to characterize the entire context.

It is precisely the different nature of convents, monasteries and professed houses, linked also to the rules of the orders established within the buildings, that characterizes not only the

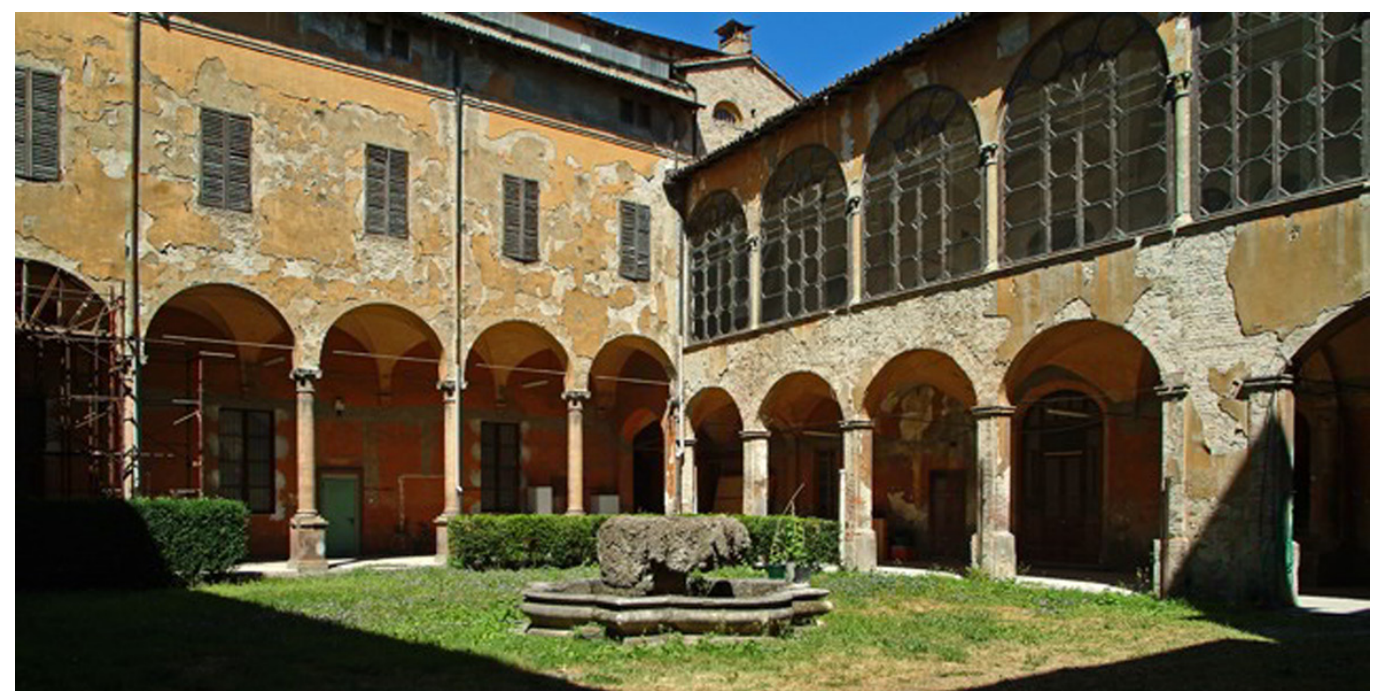


Fig. 7. Aerial photo of the urban fabric of the area surrounding the Convent of San Francesco del

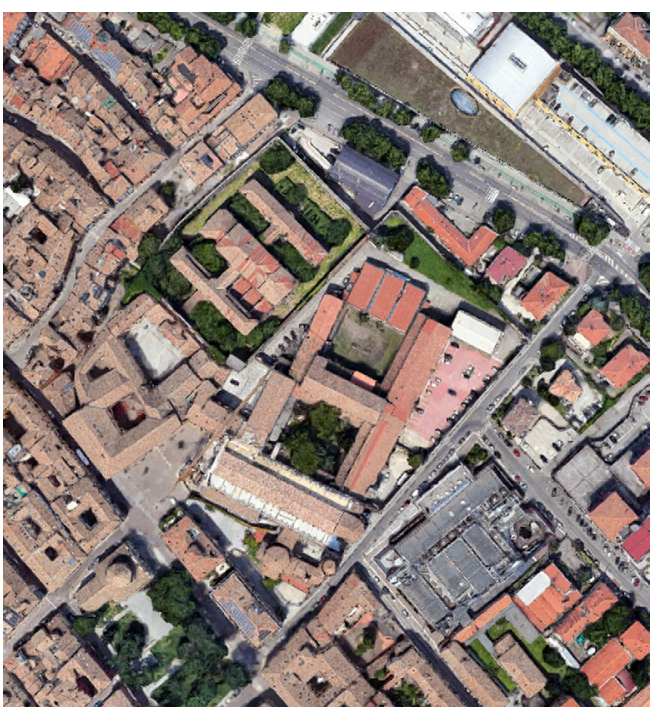

typological, distributive and fruitive internal aspects, but also the greater or lesser 'openness' towards the outside, the role assumed by the buildings intended for worship, up to the greater or lesser presence of support structures for the internal life of these organisms, linked to the sustenance of those who live there.

In order to analyze in a methodologically correct and precise way the effects on the urban fabric induced by the construction of these structures, it should be possible to consult the historical cartography relating to the individual periods of settlement of each analyzed organism, but given the distance in time of the settlement of the systems under investigation,

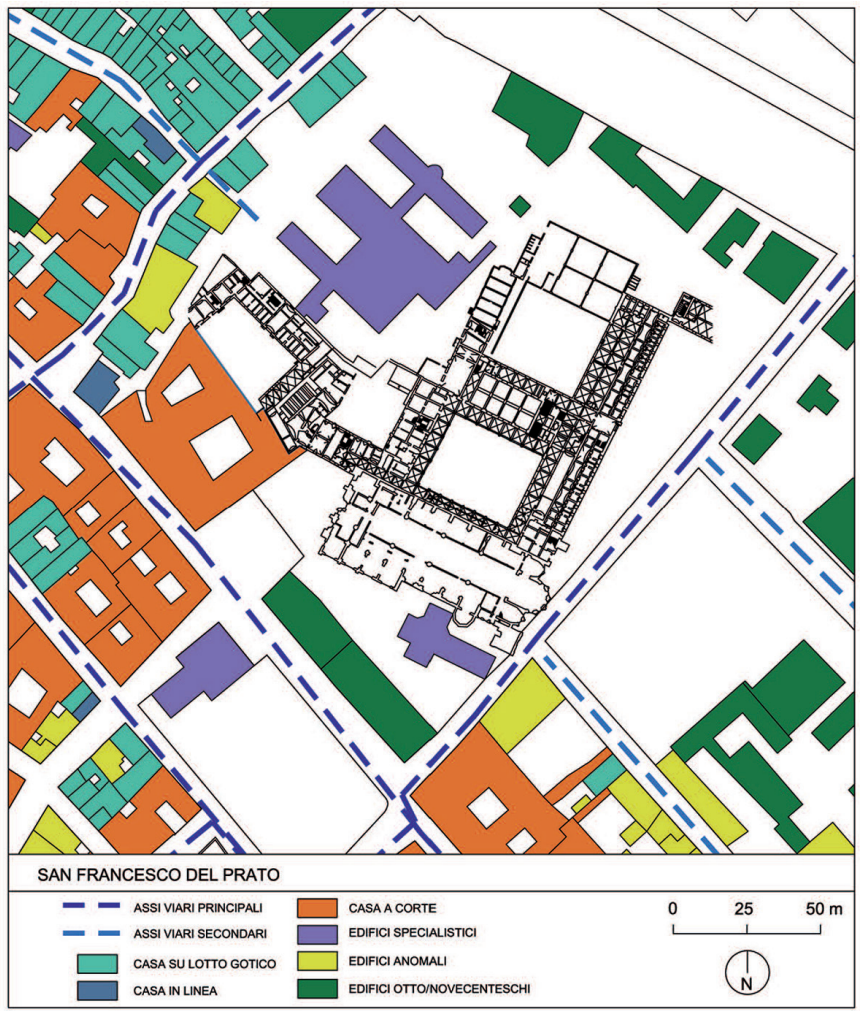


this mode of analysis of the urban fabric by cartographic comparison carried out at chronologically successive historical thresholds is impossible.

For this reason, in search of a method that would in any case make it possible to know and understand the dynamics of transformation and conditioning triggered on the different contexts of the settlement of religious organisms, we have resorted to the typological analysis of the buildings of the historic center of the city, using this way of reading urban phenomena as a tool for understanding the dynamics of settlement, associating, in a chronological sense, the different types still recognizable today to the historical periods to which their settlement can be traced, with a margin of error decidedly acceptable, given the remoteness in time of the periods in question.

In fact, from the recognition of the different historical settlement typologies, relating in particular to residential buildings, it is possible to deduce an approximate dating of the urban fabric layout, in association with historical studies on the shape and extension of the city in the various eras, contextualizing in a temporal sense the relationship between the layout of the residential and religious buildings, in order to understand, through this contextualization, the dynamics of mutual conditioning between monastic and conventual buildings and the surrounding fabric.

A typological analysis carried out on the consistency of the urban fabric today, however, considers not only the fabric itself in its present form, i.e. as the result of numerous urban transformations that have taken place over the centuries, but also and above all the religious buildings as they present themselves today, i.e. in a very different guise from the initial one, often the result of fifteenth-sixteenth-century re-foundings that have strongly altered the original state of the structures, both from a typological and dimensional point of view.

The building type (house on a Gothic lot, courtyard house, house in line, specialized buildings, anomalous buildings, nineteenth/twentieth century building), through the study of its

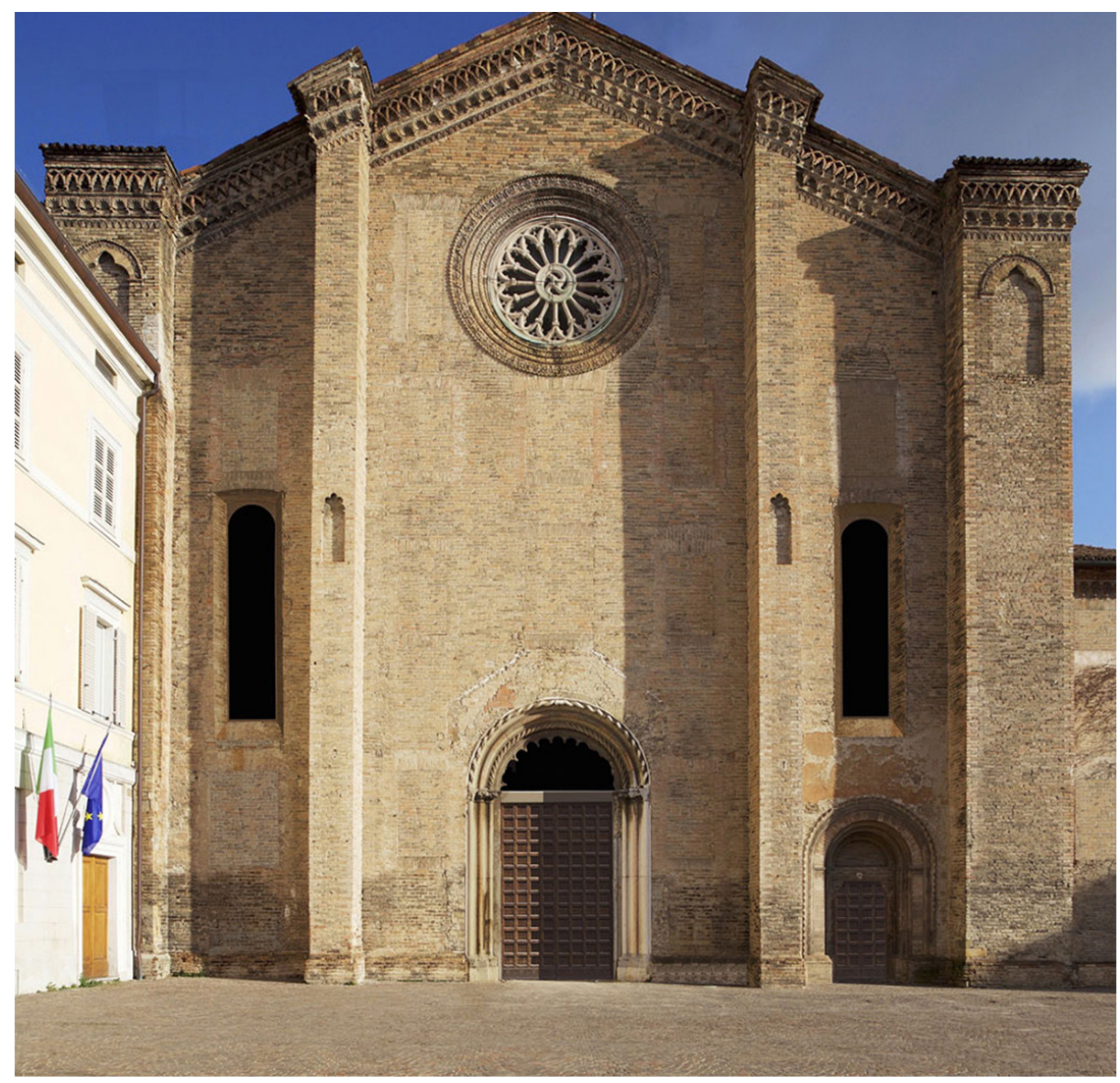


Fig. 10. Aerial photo of the urban fabric of the Convent of the Santissima Annunziata.

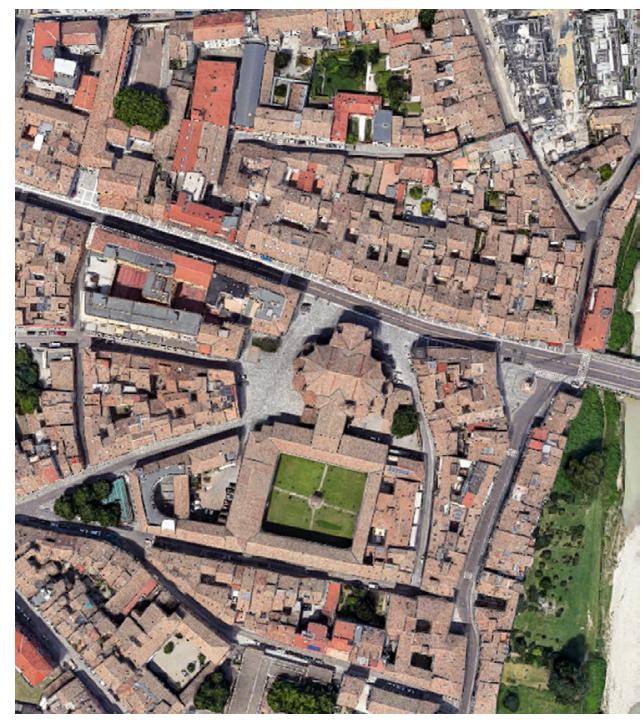

characteristic parameters (structural and distributive arrangement, ways of aggregation) has therefore been used as an interpretative code of the urban fabric, allowing a general dating of the structures adjacent to the religious organisms analyzed (fig. 3).

Through these readings, interesting considerations emerged, which lead to the identification of two different categories of conditioning: the one induced by monastic and conventual buildings on the urban fabric and on the routes, in the case of settlements in areas outside the already consolidated city, and the one mainly suffered by the structures themselves by the existing routes and buildings, in the case of settlements where the city was already compact, consolidated in its morphology and in its 'urban' structure.

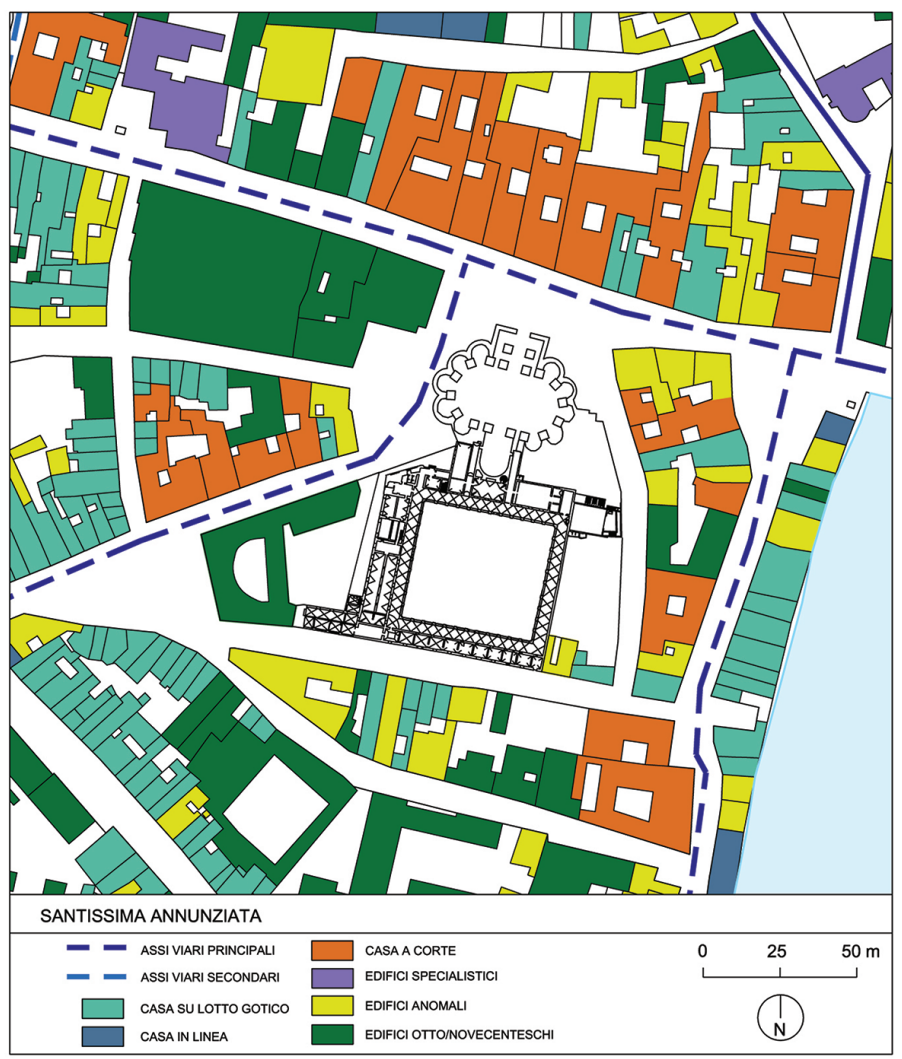

Fig. I I. Typological analysis of the urban fabric of the surrounding area The Convent of the Santissima Annunziata. Origina scale of the drawing l:2.500. 
As usual, the analysis was carried out using drawing first as a tool for reading and investigation and then as a means of graphic representation of the results of the previous analysis, characterizing itself as an element of connection between past and present, aimed at understanding the peculiarities of the urban transformations occurred.

The reading/interrogation of the urban fabric has also been deepened by moving from the urban scale to the architectural scale, where the buildings are still existing today and can therefore be visited and surveyed, through the investigation of the functional motivations of the plan, which allow the knowledge of the uses currently prevalent compared to the original ones, and the building features relating in particular to the planimetric organization of the main body, the entrance and stairway, the organization of the spaces of the cloisters and gardens.

From a reading of the urban cartography with the location of the monastic structures, of more remote foundation, it is clear how these organisms, mostly large in size, settled in areas outside the city walls of the time, settling along the main routes out of the city in the direction of other important urban poles in the territory, thus undergoing a conditioning by the road infrastructure and canals, along which they settled to allow internal production activities.

Analyzing, for example, the monastery of San Paolo (figg. 4, 5, 6), it emerges that the urban fabric is characterized by linear blocks arranged along the road routes that define the boundaries of the monastery, within which there are mainly typological categories that can be traced back to the courtyard houses, in the first section, and the house on a Gothic lot in the part facing north; the presence of large areas characterized by a building morphology composed of single Gothic lot cells, particularly near the monastic structures, should be put in relation to the large number of ancillary appurtenances to the religious buildings, which gave impetus to the construction in emphyteusis of a large number of houses for people who in various ways had to do with the economy of the monasteries.

On the other hand, there is a different discourse regarding the convent buildings, for which it is difficult to trace unitary ways of relating to the context, both as a conditioning suffered by the surroundings and as induced on it: by way of example, just think of the convents of San Francesco del Prato (figg. 7, 8, 9) and San Luca degli Eremitani, perhaps the oldest settled in the city and whose structures still exist today, both disused: both of these convents in fact

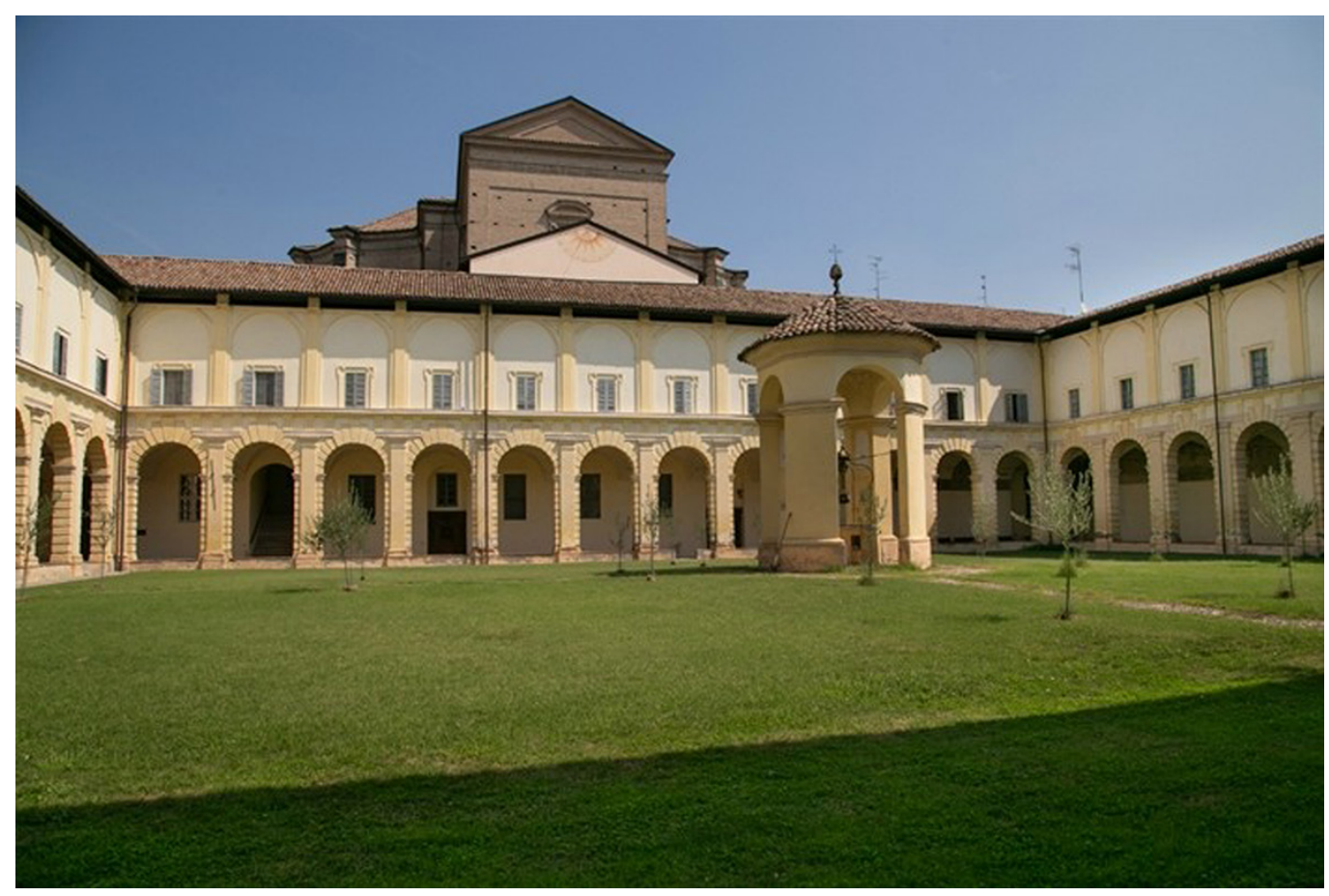


settled in large blocks with irregular shapes, defined by the routes out of the city, but they did not adapt to the orientations established by them and around them the city grew in a different way.

Some convents are strongly subject to conditioning by the paths along which they are located, often without causing repercussions on the urban morphology of the surrounding city, as in the case of Santa Maria del Carmine, literally wedged between the bed of the stream and the sediment of the walls of I 100.

The seventeenth-century convents of San Francesco di Paola (fig. I3) and Annunziata (figg. $10,11,12$ ) in the Oltretorrente are different in terms of history and period of settlement, or rather, re-foundation, and have settled in an already structured city, which they have in turn strongly influenced in different ways.

The conditionings on the urban fabric of which we have more detailed information regard the transformations that took place after the suppression of the religious Orders and the consequent reuse of the buildings, which underwent numerous modifications in order to adapt to the new functions installed; obviously, the most evident ones concern the replacement of some buildings, through the demolition and reconstruction of those that were more difficult to accommodate the new functions or those that originally housed marginal functions with respect to the complex, with strong repercussions on the urban design of the immediate context of belonging.

\section{Conclusions}

Monasteries, convents, colleges, hospices, first in their settlement, then in their growth and continuous transformation over time, have been elements characterizing the urban evolutionary dynamics, starting from their urbanization, up to the refoundation, expansion, unification and modification, as the settlement and evolution of specialized architecture has acted as a driving force for many changes of economic, functional and social character that have resulted in the modification of urban contexts related to individual religious complexes. With the exception of the place of worship par excellence, the Church, it is the organisms connected to it that have determined, both in terms of size and function, a coverage of the urban territory so significant as to characterize morphologically the city, not only in the blocks of strict relevance, but also in those immediately adjacent.

Above all through the parts functionally weaker as accessories, which as ramifications have been articulated by the main bodies, usually more resistant to transformations, religious systems have dialogued with the urban fabric in a very lively transformative dynamic, which has seen especially the most marginal parts of the complexes modify, disappear or be replaced by other buildings, which establish new relationships with the surrounding city, changing the urban image.

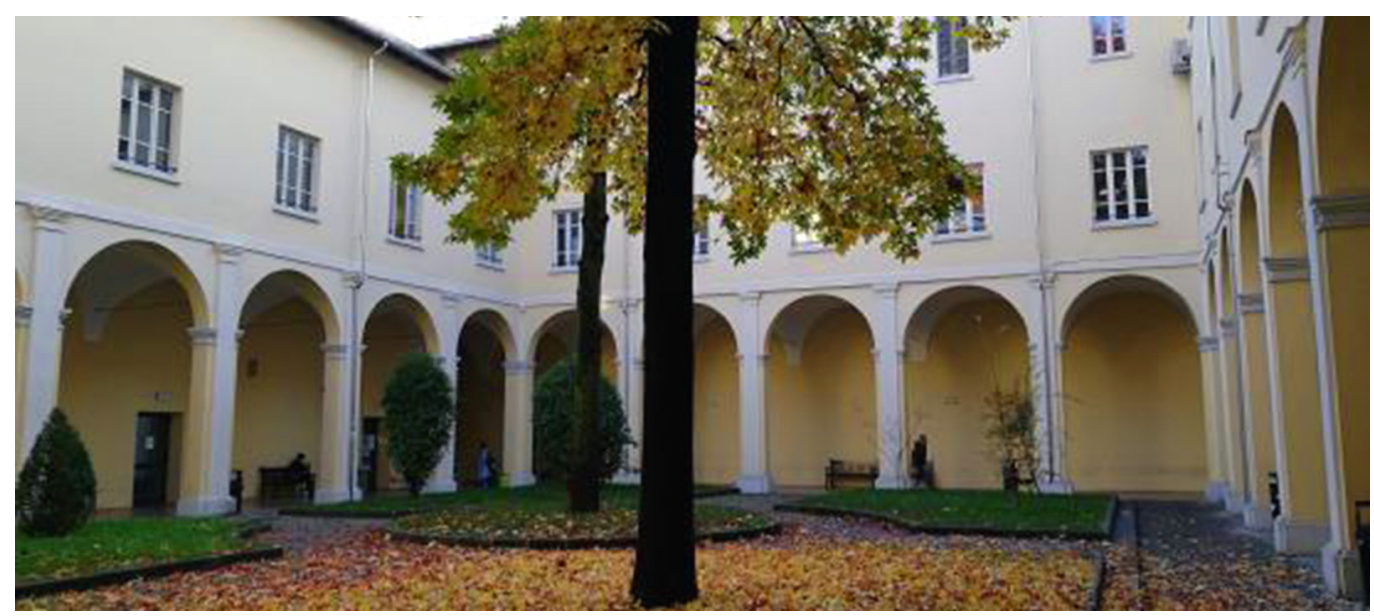




\section{References}

Aymonino Carlo (1966). Origini e sviluppo della città moderna. Padova: Marsilio.

Baculo Giusti Adriana (1996). Napoli al quattromila, assonometria e pianta sinottica della città. Napoli: Electa.

Banzola Vincenzo (a cura di). (1978). Parma: La città storica. Parma: Cassa di Risparmio di Parma.

Bertocci Stefano, Parrinello Sandro (a cura di) (2013). Architettura eremitica: sistemi progettuali e paesaggi culturali. Atti del $4^{\circ}$ Convegno internazionale di studi. Camaldoli $21-23$ settembre 2013. Firenze: Edifir.

Cavallari Murat Augusto(1968). Metodologia e metodi in tema di rioni storici: rinnovamento nel rilievo urbanistico-architettonico. Torino: UTET.

Caniggia Gianfranco, Maffei Gian Luigi (1979). Composizione architettonica e tipologia edilizia. I: Lettura dell'edilizia di base. Venezia: Marsilio.

Comune di Parma Assessorato All'urbanistica (a cura di). (1979). Disciplina particolareggiata per gli interventi nel Centro Storico: Variante al piano regolatore generale: Relazione Generale. Parma: Comune di Parma.

Conte Antonio ( 1996). II disegno degli ordini: Monasteri, conventi, abbazie e grancie della Basilicata, Potenza: Ermes.

Coppo Secondino, Boido Cristina (a cura di). (20l0). Rilievo urbano. Conoscenza e rappresentazione della città consolidata. Firenze: Alinea.

Cundari Cesare, Carnevali Laura (a cura di). (2003). Il rilevamento urbano: tipologia, procedure, informatizzazione: Materiali della ricerca co-finanziata dal MIUR nel 2000. Roma: Kappa edizioni.

Cundari Cesare (a cura di). (2005). II rilievo urbano per sistemi complessi: Un nuovo protocollo per un sistema informativo di documentazione e gestione della citta: Materiali dalla ricerca co-finanziata dal MIUR nel 2002. Roma: Kappa edizioni.

Da Mareto Felice (1975). Parma e Piacenza nei secoli: Piante e vedute cittadine delle antiche e nuove province parmensi. Parma: Deputazione di storia patria per le province parmensi: Rotary Club.

Dalcò Fabrizia (20 I5). Monasteri e conventi femminili nella Parma medievale. Parma: Nuova Editrice Berti.

Giandebiaggi Paolo, Melley Maria Evelina, Vernizzi Chiara et al. (a cura di). (2019). Gli organismi religiosi nella trasformazione urbana. Analisi e rilievo nella città di Parma. Roma: Aracne Editrice.

Mandelli Emma, Duvernoy Sylvie (a cura di)(2002). Il disegno della città: opera aperta nel tempo. Atti del convegno internazionale AED, San Gimignano 29-30 giugno 2002. Firenze: Alinea.

Melley Maria Evelina (2012). I chiostri negli organismi religiosi di Parma. Geometria, proporzioni, architettura. Fidenza (PR): Mattioli 1985

Miani Uluhogian Franca, 1984. Le immagini di una città: Parma (secoli XV-XIX): Dalla figurazione simbolica alla rappresentazione topografica. Parma: Casanova.

Mumford Lewis (1963). La città nella storia.Voll. I-3. Milano: Edizioni di Comunità.

Rossi Michela (2004). Strade d'acqua: Navigli, canali e manufatti idraulici nel parmense: Dal rilievo del territorio al disegno del paesaggio. Fidenza (PR): Mattioli 1885.

Vernizzi Chiara (2004). Parma e la via Emilia. Città storica, città moderna e asse fondativo: Rilievo e rappresentazione. Fidenza (PR): Mattioli 1885

Vernizzi Chiara, Bontempi Donatella (20I5). La rappresentazione della città per lo studio dei fenomeni urbani. Evoluzione metodologica attraverso casi studio. In Marotta Anna, Novello Giuseppina (a cura di). Disegno \& città: cultura, arte, scienza, informazione. Atti del $37^{\circ}$ Convegno Internazionale dei docenti delle discipline della rappresentazione. Torino I7- 19 settembre 20 I5. Roma: Gangemi Editore, pp. 87|-878.

\section{Authors}

Paolo Giandebiaggi, Università di Parma, paolo.giandebiaggi@uniprit Chiara Vernizzi, Università di Parma, chiara.vernizzi@unipr.it

To cite this chapter. Giandebiaggi Paolo, Vernizzi Chiara (2020). Gli organismi religiosi nella trasformazione della città europea: dal rilievo alla definizione di una identità urbana/Religious building in the transformation of the European city: from survey to the definition of an urban identity In Arena A., Arena M., Brandolino R.G., Colistra D., Ginex G., Mediati D., Nucifora S., Raffa P. (a cura di). Connettere. Un disegno per annodare e tessere. Atti del $42^{\circ}$ Convegno Internazionale dei Docenti delle Discipline della Rappresentazione/Connecting. Drawing for weaving relationships. Proceedings of the 42th International Conference of Representation Disciplines Teachers. Milano: FrancoAngeli, pp. | | 6 |- | 82 